\title{
LA ECONOMÍA ESPIRITUAL DEL CONVENTO DE SANTA CLARA DE SANTAFE DE BOGOTA, SIGLOS XVII Y XVIII
}

Constanza Toquica $C$.

El 13 de enero de 1625, en Santafé, el arzobispo Fernando Arias de Ugarte firmó la escritura de fundación del convento de Santa Clara, concebido por él como una obra pía para doncellas virtuosas, honradas y de limpia sangre. Para ello destinó 40 mil patacones que se erigirían en "bienes espirituales". 2 Aunque explícitamente fue fundado para la protección de las doncellas y la alabanza de Dios, el convento desarrolló además de funciones sociales y religiosas, importantes funciones económicas como institución de crédito.

Hasta finales del siglo XVI y comienzos del XVII se fundaron los primeros conventos coloniales en la Nue-

1 Este artículo forma parte de la investigación que adelanta la autora para su tesis de Maestría en Historia sobre "El Convento de Santa Clara de Santafé, siglos XVII y XVIII", dirigida por la profesora Ana María Bidegaín de la Línea de Investigación en Historia de las Religiones del Departamento de Historia de la Universidad Nacional de Colombia. Los aspectos económicos y sociales de este estudio fueron financiados por Colciencias.

2 Archivo Privado del Convento de Santa Clara de Santafé de Bogotá. En adelante A.C.S.C. (Santafé de Bogotá), Copia manuscrita de los registros y protocolos en los que consta la fundación original del Convento, Santafé, enero 7 de 1792. 
va Granada ${ }^{3}$ y en Hispanoamérica. Lo tardío de este hecho obedeció a la escasa población femenina que arribó al Nuevo Mundo tras los primeros años de conquista. Las esposas, hijas y parientas de los conquistadores llegaron a habitar las nuevas ciudades de traza reticular que comenzaron a alterar el paisaje del Nuevo Mundo después de la pacificación. ${ }^{4}$

Las mujeres de la sociedad patriarcal de entonces sólo podían escoger entre el matrimonio, el convento, o una soltería socialmente incómoda porque podían caer en la prostitución o en la mendicidad al no haber quien se hiciera cargo de ellas. El convento femenino fue el único lugar donde las mujeres criollas de la elite tuvieron una alternativa de vida diferente a la doméstica, impuesta por su condición de esposas y madres. Es importante redimensionar la figura de la mujer religiosa en nuestro contexto. Las mujeres de este periodo no vivieron todas tan a la sombra de los hombres: las religiosas, las viudas de la elite, y las mujeres cabezas de familia de algunas castas, formaron un grupo de población femenina en el que se puede observar dicha autonomía.

Este artículo aborda al convento femenino desde la diversidad de sus funciones económicas y sociales. El monasterio fue concebido, para esta in-

3 Germán Franco Salamanca, Templo de Santa Clara Bogotá, Bogotá, Colcultura, 1987, pp. 19 - 20. Para referirnos sólo a los conventos de clarisas, vemos que el de Tunja, fue fundado en 1573, el de Pamplona, en 1584, el de Cartagena, en 1621, el de Mérida, en 1651.

4 Inmaculada de la Corte Navarro, "Aportaciones reales a los conventos de monjas en México, siglo XVI. El Caso de Nuestra Señora de la Concepción", El Monacato femenino en el Imperio Español, Monasterios, beatarios, recogimientos y colegios. Memoria del II Congreso Internacional. Coord. Manuel Ramos Medina, México, Condumex, 1995, pp.138 - 139.

5 Asunción Lavrin, "Investigación sobre la mujer de la colonia en México: siglos XVII y XVIII", Asunción Lavrin (comp.), Las mujeres latinoamericanas, México, F.C.E., 1985, "La viudez traía consigo una gran libertad para las mujeres. [...] tenían el manejo de una gran cantidad de facultades, particularmente si perte necían a las clases que eran propietarias de bienes, [...] La idea de que la mujer de la colonia no trabajaba o tenía muy poca fuerza económica tiene que ser revisada. La fuerza económica no debería definirse simple mente en términos del sueldo que se gane. [...] Si la fuerza económica se mide en términos del acceso a la riqueza y a la propiedad, las mujeres de la elite social obtenían una fuerza muy considerable como herederas de sus padres o esposos. Si el trabajo que se dedicaba al desempeño de cargos no remunerados se considera como un activo económico, las mujeres de las clases bajas eran igualmente muy valiosas. Tanto en las áreas rurales como en las urbanas las mujeres indígenas y castizas estaban dedicadas a ocupaciones muy diversas: tenían puestos en el mercado [...]. Trabajaban como criadas, nodrizas, lavanderas, y vendedoras ambulantes, ayudando de esta manera al sostenimiento de su familia y de ellas mismas, y al rendir estos servicios se convertían en un elemento indispensable para la economía local [...] en los ingenios de azúcar trabajaban mujeres esclavas; los centros mineros requerían mujeres como cocineras, criadas o prostitutas [...] Las ocu paciones tradicionales de las mujeres en los siglos XVII y XVIII eran la de profesora (amigas) o costureras, en las que ganaban sueldos sumamente bajos [...1. Las instituciones religiosas femeninas también deberían tomarse en consideración como parte importante de la clase propietaria. [...]". pp. 61 - 73. 


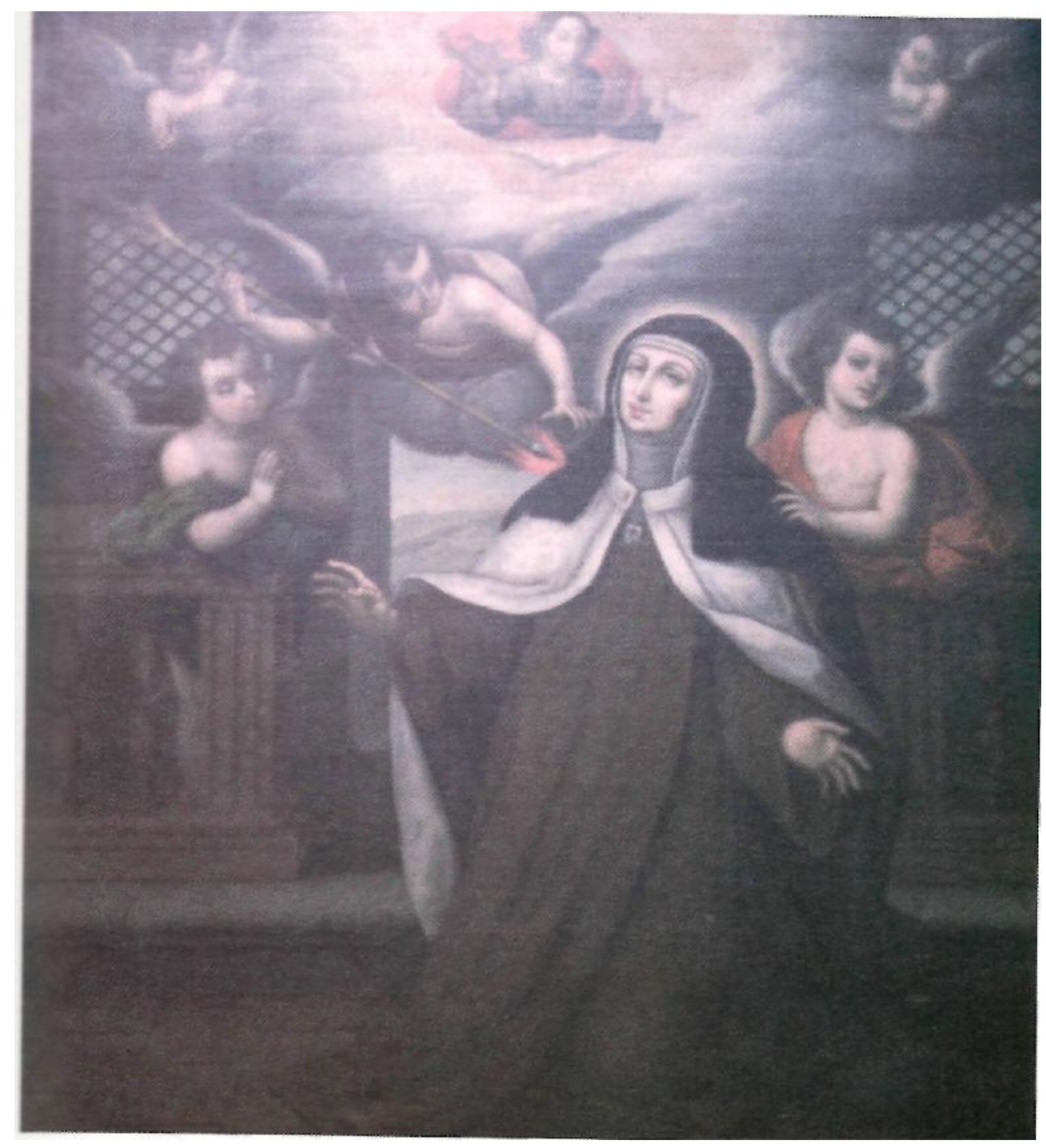

Visión de Santa Teresa de Jesús. Oleo sobre tela. Anónimo. Siglo XVI.

Colección Templo Museo de Santa Clara, fotografía de Gustavo Echeverri. Referencia tomada de Germán Franco Salamanca, Templo de Santa Clara, Bogotá, Bogotá, Colcultura, 1987, p. 204. 
vestigación, como un sistema de sistemas, lo cual condujo a pensarlo como una estructura plurifuncional, ${ }^{6}$ sin que su actividad estuviera determinada por un solo aspecto, fuera este económico, social, religioso o político. Las funciones desarrolladas por él estaban estrechamente ligadas entre sí. Uno de los aspectos que más fuertemente las unió fue la religión y por esto es el código de referencia constante para la interpretación de las variadas funciones conventuales.

El convento de Santa Clara de Santafé de Bogotá actuó como una institución de crédito local. La necesidad de dinero efectivo, causada por la decadencia de la encomienda y la minería, y las consecuentes depresiones económicas de los siglos XVII y XVIII, hicieron que los santafereños tuvieran que recurrir a él.

Como institución social, el convento permitió al grupo de españoles y a sus descendientes proteger a sus doncellas de los peligros de una mezcla indeseable con negros, mulatos o mestizos cuando los recién llegados funcionarios peninsulares o los ricos propietarios criollos escaseaban, y no se podían efectuar las anheladas alianzas. Socialmente el convento fue un lugar de formación y de habitación para las doncellas blancas y algunas mestizas. Huérfanas, viudas, y niñas ingresaron para convertirse en monjas o para ser protegidas temporalmente. También lo habitaron criadas y esclavas.

Como institución religiosa vivió en lo posible de acuerdo con las normas dictadas en el Concilio de Trento. La regla pretendió desarrollar el modelo de perfección y santidad en las religiosas según la pedagogía femenina postridentina, aunque el comportamiento de las religiosas no siempre fue ejemplar. ${ }^{7}$ La función política de la inversión religiosa se evidenció a través de las dotes, limosnas, obras pías y las hermandades. Para los vecinos de Santafé que se asociaron en hermandades, el convento y la iglesia fueron un puente entre el cielo y la tierra.

\footnotetext{
${ }^{6}$ Michel De Certeau, La escritura de la historia, México, Universidad Iberoamericana, 1985, pp. 137 - 140 y 175 -181. El concepto de plurifuncionalidad fue trabajado por éste autor al referirse a la historia religiosa de los siglos XVII y XVIII. En él explica la forma como se interrelaciono el sistema religioso con otros sistemas como el económico, el político, el social, según el momento histórico. En el siglo XVII, según él, la religión atraviesa poderosamente las otras instancias; por ello señala, la clave teológica, como la clave central para leer la historia del siglo XVII y la primera mitad del XVIII.

7 A.C.S.C. (Santafé de Bogotá), Diálogo ejemplificante entre una religiosa y su confesor, (s.f.).
} 


\section{LA FUNCION ECONOMICA DEL CONVENTO}

Durante las dos primeras décadas del siglo XVII apenas se insinuaba la segunda crisis minera. Entonces tuvo lugar el éxodo de los mineros más poderosos de Remedios, Mariquita y Zaragoza, hacia los centros urbanos donde podían procurarse un goce tranquilo de las riquezas acumuladas. ${ }^{8}$ Santafé fue uno de esos centros urbanos. Cuando se comenzaron a sentir los críticos efectos de la inadecuada apropiación y explotación de la tierra, de la mano de obra indígena y de las minas, el convento de Santa Clara estaba prestando dinero a censo, ${ }^{9}$ dentro de una lógica que Le Goff ${ }^{10}$ llamó de economía de la salvación y Kathryn Burns," de economía espiritual.

Los movimientos de ésta economía se iniciaban el día de profesión de la novicia, cuando el matrimonio con Cristo era respaldado con el pago de 2.000 patacones de dote. Así se sellaba el compromiso místico de la profesa, y se abría el camino al crédito para su familia. Por medio de las dotes el convento adquiría una porción del total del dinero efectivo que recaudaba, del cual depositaba una parte ${ }^{12}$ en la Caja de Depósitos del Convento y la otra en la Caja Real. El dinero de la Caja de Depósitos era utilizado en los censos, los cuales rentaban el 5\% anualmente.

Los libros de cuentas del monasterio, ${ }^{13}$ los cuadernos de censos, las Relaciones Juradas, las escrituras de censos, y las demandas de los mismos ${ }^{14}$ indicaron el crédito otorgado por el monasterio y permitieron observar la movilidad de capitales y bienes. De acuerdo con el contenido de la docu-

${ }^{8}$ Germán Colmenares, Historia económica y social de Colombia ;537 - 17/9, Santafé de Bogotá, Tercer Mundo, 1997, p. 437.

9 Manuel Teruel Gregorio de Tejada, Vocabulario básico de la historia de la Iglesia, Barcelona, Crítica, 1993, pp. 440 - 442. "Los censos consistían en la sujeción de bienes inmuebles, al pago de un canon o rédito anual en retribución de un capital, que se recibía generalmente en dinero \{censo consiliativo), o del dominio pleno (censo reservativo) o menos pleno (censo enftéutico) de un bien que se transmitía de los mismos bienes.[...] El término general censo (census) en la Edad Moderna era sinónimo de renta (redittus) [...]"

${ }^{10}$ Jacques Le Goff, La bolsa y la vida. Economía y religión en la Edad Media, Barcelona, Gedisa, 1996.

${ }^{11}$ Kathryn Burns, "Conventos, criollos y la economía espiritual del Cuzco, siglo XVII", Memoria del II Congreso internacional El Monacato Femenino en el Imperio Español. Monasterios, beatarios, recogimientos y colegios, México, Condumex, 1995, pp. 311 - 317.

12 Ver tabla "Comparación de los valores más altos de los ingresos del Convento de Santa Clara durante los siglos XVII y XVIII", aquí se observa que los mayores recaudos provenían de los réditos (o intereses) y principales (o capitales) cancelados, de los censos.

13 A.G.N. (Santafé de Bogotá), Conventos, t. 27, 46, 47, 55, 58, 63, 64, 65, 67, 70, 76, 77.

14 A.G.N. (Santafé de Bogotá), Conventos, Censos Redimibles y Miscelánea. 
mentación, la información económica fue reconstruida en torno a tres ejes ${ }^{15}$ : la estructura de los ingresos, la estructura de los egresos y la composición de los bienes. La estructura de los ingresos permitió conocer los grupos sociales e instituciones religiosas con las que se relacionó el convento, las funciones que desarrolló y el espacio geográfico en el que influyó. Con la estructura de los egresos se construyó un pasadizo que atravesó los gruesos muros de la clausura, al mismo tiempo que la estructura de los bienes permitió conocer sus propiedades rurales y urbanas, y sus bienes de capital.

\section{Los ingresos del convento}

Diferentes instituciones eclesiásticas coloniales recibían dinero, propiedades urbanas, tierras y ganado de los fieles, destinados al sostenimiento del culto, de los clérigos, de las monjas y a la salvación de sus almas. Así pagaban las dotes, obras pías, capellanías y cuotas de las hermandades. Iglesias, conventos, monasterios y religiosos, hacia finales del siglo XVII y hasta el fin del periodo colonial, eran dueños de cerca de la mitad de las tierras planas fértiles de la Sabana. ${ }^{16}$ Los ingresos por el pago de los réditos de los censos contribuyeron significativamente a su crecimiento, tanto que se conformaron en instituciones crediticias, ${ }^{17}$ debido a la acumulación del dinero en efectivo proveniente del 5\% pagado semestralmente por quienes tenían sumas otorgadas a censo sobre sus inmuebles, los cuales en diversas ocasiones también pasaban a formar parte de los bienes de la institución eclesiástica, cuando se tenían que rematar por atraso en el pago de los réditos.

En un principio el convento de Santa Clara de Santafé se sostuvo con las dotes otorgadas por el fundador a 12 novicias, 24 mil patacones de los 40 mil destinados a la fundación, ${ }^{18}$ que comenzó a otorgar a censo desde 1628 . El hecho de su casi inmediato desempeño como institución de crédito, se

${ }^{15}$ Agradezco las sugerencias que al respecto hizo el profesor Mermes Tovar.

16 Juan A. Villamarín, "Haciendas en la Sabana de Bogotá, en la época colonial: 1539 - 1810", Enrique Florescano (ed.), Haciendas, Latifundios y Plantaciones en América Latina, México, Siglo XXI, 1975, p. 334.

${ }^{17}$ Germán Colmenares, Haciendas de los Jesuítas en el Nuevo Reino de Granada- Siglo XVIII, Bogotá, Antares Tercer Mundo, 1969. p. 26. Por ejemplo, el autor dice acerca de la Compañía de Jesús que: "[...] su capacidad como organismo financiero de crédito derivaba, por razones morales y en virtud del mecanismo jurídico de los censos, de su calidad de propietaria de bienes inmuebles."

18 A.C.S.C. (Santafé de Bogotá), Copia manuscrita de los registros y protocolos en los que consta la fundación original del Convento. Santafé, enero 7 de 1792. 
ECONOMIA ESPIRITUAL

\section{Tabla 1. COMPARACION DE LOS VALORES MAS ALTOS DE LOS INGRESOS DEL CONVENTO DE SANTA CLARA DURANTE LOS SIGLOS XVII Y XVIII}

\begin{tabular}{|c|c|c|c|c|}
\hline PERIODO & $\begin{array}{c}\text { REDITOS } \\
\text { DE CENSOS }\end{array}$ & $\begin{array}{l}\text { ARRIENDOS } \\
\text { URBANOS }\end{array}$ & $\begin{array}{l}\text { FRUTOS } \\
\text { DE LAS } \\
\text { ESTANCIAS }\end{array}$ & $\begin{array}{l}\text { PRINCIPALES } \\
\text { DE CENSOS } \\
\text { REDIMIDOS }\end{array}$ \\
\hline 1661(feb.)-1664(mar) ${ }^{19}$ & 25.248 p. 5 r. $^{20}$ & 45 p. $4 r$. & 648 p. Ir. & 23.054 p. \\
\hline 1681(nov)-1684(nov) ${ }^{21}$ & 13.406 p. & 306 p. 4 r. & 758 p. & \\
\hline $\begin{array}{l}\text { 1687(nov)-1690(nov) }{ }^{22} \\
1719 \text { (nov)-1720(nov) }\end{array}$ & $\begin{array}{l}11.962 \text { p. } 5 \mathrm{r} . \\
9.843 \text { p. } 5^{1} / 2 \text { r. }\end{array}$ & $\begin{array}{l}725 \text { p. } \\
405 \text { p. } 6 r .\end{array}$ & 1.364 p. 5 r. & \\
\hline 1725(nov)-1726(nov) $)^{24}$ & 7.902 p. $4 \frac{1}{2}$ r. & 425 p. 4 r. & & $1.450 \mathrm{p}$. \\
\hline 1728(nov)-1729(nov) ${ }^{25}$ & 7.907 p.5r. lq. & 488 p. 7r. 3q. & & \\
\hline 1734(nov)-1735(nov) ${ }^{26}$ & 4.825 p. $2^{1} /{ }_{2} \mathrm{r}$. & 704 p. & & $13.752 \mathrm{p}$. \\
\hline 1735(nov)-1736(nov) ${ }^{27}$ & 6.249 p. 2r. lq. & 551 p. & & 17.007 p. 4 r. \\
\hline 1737(nov)-1738(nov) ${ }^{28}$ & 5.303 p. 4 r. & $660 \mathrm{p}$. & & 7.507 p. \\
\hline 1738(nov)-1739(nov) & 7.220 p. 4 r. & $668 \mathrm{p}$. & & 4.002 p. $4 r$. \\
\hline 1741(nov)-1742(nov) $)^{30}$ & 6.428 p. $3^{1} / 2 r$ & $661 \mathrm{p}$. & & 9.450 p. \\
\hline 1742(nov)-1743(nov) ${ }^{31}$ & 8.496 p. $2 \frac{1}{2}$ r. & $458 \mathrm{p}^{1 / 1} / 2 \mathrm{r}$ & & $11.300 \mathrm{p}$. \\
\hline 1751(nov)-1752(nov) ${ }^{32}$ & 11.992 p.3r.3q. & 731 p. & & \\
\hline 1759(nov)-1760(nov) ${ }^{33}$ & 8.112 p. $6 \frac{1}{2} \mathrm{r}$ & 395 p. & & $3.400 \mathrm{p}$. \\
\hline TOTALES: & 134.904 p. & 7.227 p. Vi r. & 2.770p. 6r. & $90.922 \mathrm{p}$. \\
\hline
\end{tabular}

19 A.G.N. (Santafé de Bogotá), Conventos, t. 77, f'f. 768r - 864v.

20 Los libros de cuentas del convento, aunque traían estos rubros separados, no sumaban cada clase indepen dientemente. Totalizaban dentro de un gran total de ingresos o cargo, y egresos o data. Por ésta razón tuvo que ser sumado cada rubro independientemente, en base 8, ya que 1 patacón (p), equivalía a 8 reales (r), 8 reales eran 16 cuartillos (q).

21 A.G.N. (Santafé de Bogotá), Conventos, t. 63, ff. 48r - 56v.

22 A.G.N. (Santafé de Bogotá), Conventos, t. 67, ff. 733r - 936v.

23 A.G.N. (Santafé de Bogotá), Conventos, t. 65, ff. 749r - 777v.

24 A.G.N. (Santafé de Bogotá), Conventos, t. 46, ff. 233r - 248v.

25 A.G.N. (Santafé de Bogotá), Conventos, t. 27, ff. 757r - 790v.

26 A.G.N. (Santafé de Bogotá), Conventos, t. 46, ff. 285r - 299v.

27 A.G.N. (Santafé de Bogotá), Conventos, t. 76, ff. Ir - 23v.

28 A.G.N. (Santafé de Bogotá), Conventos, t. 67, ff. 279r - 294 v.

29 A.G.N. (Santafé de Bogotá), Conventos, t. 58, ff. 939r. - 954v.

30 A.G.N. (Santafé de Bogotá), Conventos, t. 76, ff. 38r - 57 v.

31 A.G.N. (Santafé de Bogotá), Conventos, t. 67, ff. 259r - 273 v.

32 A.G.N. (Santafé de Bogotá), Conventos, t. 67, ff. 569r - 584v.

33 A.G.N. (Santafé de Bogotá), Conventos, t. 67, ff. 585 - 600r. 
debió en parte a la crisis causada por la reducción de mano de obra ${ }^{34}$ indígena para trabajar en la minería y en la agricultura.

En la tabla 1 de comparación de los ingresos más altos del convento durante los siglos XVII y XVIII se observa que en 14 de las 15 cuentas estudiadas, entre 1661 y $1760,{ }^{35}$ la mayor cantidad de ingresos provino en primer lugar de los réditos y en segundo lugar de los principales ${ }^{36}$ de censos redimidos, pese a que una de las características más marcadas de los recaudos durante los dos siglos fue el incumplimiento en el pago de réditos y principales. La falta de pago se debió a la ausencia de una adecuada organización de las religiosas para cobrar, la probable corrupción de algunos de los síndicos del monasterio y a factores externos como el descenso en la explotación de la minería del oro y a la improductividad de la economía agrícola colonial. ${ }^{37}$ Las haciendas de la Sabana de Bogotá, ${ }^{38}$ proveían a la ciudad de Santafé, pero sobretodo a las minas del Tolima y Antioquia y al mercado de Cartagena. Una vez perdieron éstos mercados la producción declinó, pues la inversión de capital dependía de ellos. Con la declinación gradual de la producción, vino la decadencia económica de sus dueños quienes tuvieron que buscar empleos burocráticos, dedicarse al comercio, y al ser esto insuficiente, prestar a censo.

34 Germán Colmenares, Haciendas de los Jesuítas, pp. 39 - 40, "Antes de fundarse el colegio de Santa Fe, a comienzos del siglo XVII, por ejemplo, el P. Diego de Torres había hecho valiosas observaciones respecto al alarmante descenso de la población indígena, hecho que no tardó en comunicar a Felipe III. El jesuíta señalaba con precisión las causas de la disminución de indios. La atribuía a los desplazamientos que los indígenas, sus mujeres e hijos estaban obligados a realizar para proveer de leña a la ciudad. Al desequilibrio que se producía con el drenaje de la población femenina para servir en las casas [...]. A la venalidad de las encomiendas, por las que se ofrecían diez o doce mil pesos que producirían 600 o 700 ps. con 150 o 200 indios."

${ }^{35}$ A.G.N. (Santafé de Bogotá), Conventos, t. 63, ff. 48r - 56v; Conventos, t. 67, ff. 733r - 936v; Conventos, t. 65, ff. 749r - 777v; Conventos, t. 46, ff. 233r - 248v; Conventos, t. 27, ff. 757r - 790v; Conventos, t. 46, ff. 285r 299v; Conventos, t. 76, ff. 1 r - 23v; Conventos, t. 67, ff. 279r - 294v; Conventos, t. 58, 939r - 954v; Conventos, t. 76, ff. 38r - 57v; Conventos, t. 67, ff. 259r - 273v; Conventos, t. 67, ff. 569r - 584v; Conventos, t. 67, ff. 585 - 600r.

${ }^{36}$ Así eran llamadas las sumas de dinero otorgadas en préstamo. Ver tabla.

37 Germán Colmenares, "Censos y capellanías: formas de crédito en una economía agrícola.", Cuadernos colombianos, vol. 1, No. 2, mayo -junio de 1974, pp. 123-143.

38 Juan A. Villamarín, "Haciendas en la Sabana de Bogotá, en la época colonial: 1539-1810", Enrique Florescano (ed.), Haciendas, Latifundios y Plantaciones en América Latina, México, Siglo XXI, 1975, p. 328. 
Según la información observada de la tabla 1, hubo un crecimiento de la demanda de crédito en la segunda mitad del siglo XVII y un descenso en el cumplimiento del pago de réditos que continuó hasta la primera mitad del XVIII. La información de los réditos de los censos, los señala cómo los ingresos más constantes a lo largo de los dos siglos, indicando un pico de alrededor de 25 mil p. entre 1661-1664. Desde ésta fecha hay un descenso de los ingresos provenientes por éste concepto, el cual se detiene entre 1734-1735, cuando los ingresos suman algo más de 4.800 p. Luego despunta levemente hasta el segundo pico significativo de los ingresos provenientes de los réditos, los cuales entre 1751 y 1752 suman cerca de 12.000 p. Éstos vuelven a bajar entre 1759-1760 registrando un valor de tan sólo alrededor de 8 mil p. Siguiendo la interpretación de la tabla de los ingresos se observan los casi 91 mil p. recaudados entre 1661-1743, por concepto de la redención de los principales prestados.

\section{Los censos}

Los censos se constituyeron en la categoría que arrojaría más luz sobre los ingresos y sobre la función crediticia del convento dentro de la sociedad local. ${ }^{39}$ Fueron transcritos, contrastados e interpretados, 262 casos, extraídos de las escrituras de censos, de los libros de cuentas, de los libros de cuentas de censos y de las relaciones juradas. Cada censo se interrogó a través de ocho variables, ${ }^{40}$ por medio de las cuales se reconstruyó una ventana por la que se observó parte del paisaje material de la ciudad y de la provincia de Santafé, y los movimientos económicos que sobre él tejió el Monasterio de Santa Clara en su interrelación con los diferentes grupos sociales; funcionarios reales, eclesiásticos, algunos comerciantes, vecinos y vecinas de la ciudad de Santafé, e instituciones religiosas, la mayoría de ellas pertenecientes a la Compañía de Jesús.

39 Asunción Lavrin, "Conventos de Monjas en la Nueva España", A. J. Bauer, La iglesia en la economía de América Latina, siglos XVI al XIX, México, Instituto Nacional de Antropología e historia, 1986, p. 198. "En todos los casos, los conventos femeninos establecieron sólidas relaciones económicas con las clases propietarias, situación ya vigente a finales del siglo XVI. Estas relaciones tuvieron como base el censo y después el depósito [como se llamaba un censo a término definido en la Nueva España]. El censo fue un fenómeno económico-legal que floreció en Nueva España en el siglo XVII y que perduró a través del siglo XVIII, aunque ya no en forma tan prominente. La raíz del censo es medieval y su uso se generalizó en las posesiones españolas de América debido a la falta de capital en dinero efectivo de muchos propietarios. $\quad{ }^{40} 1$. Fecha, 2. Nombre del censualista, 3. Nombre del censuatario y fiadores, 4. Bien censado, 5. Principal otorgado, 6. Réditos pagados, 7. Forma de pago y 8. Observaciones. 
En la séptima década del siglo XVII, como se observa en la gráfica de Principales de censos otorgados por el Convento, comienza a ascender el volumen de dinero, cuando de 13 casos de la muestra, que registran $17.169 \mathrm{p}$. prestados en la sexta década, salta a 36 casos, que ascienden a 34.169 p. entre 1661-1670. El hecho de que desde la segunda mitad del siglo XVII haya crecido la demanda de dinero al convento coincide con el diagnóstico de crisis económica en las haciendas de la Sabana que hace Villamarín. ${ }^{41}$ Mientras que en la sexta década de 13 propiedades censadas, existen 9 urbanas y tan sólo 4 rurales, en la séptima se presenta un ascenso de las propiedades rurales censadas, sobre las urbanas: de las 37, sólo 14 eran urbanas, mientras que 19 fueron rurales. ${ }^{42}$ Las haciendas y las tierras de todos los tamaños se utilizaban en agricultura y ganadería. Los cultivos más importantes en su orden, fueron el trigo, el maíz, la cebada y las papas. En ganado predominaron los ovinos. El trigo proveía los mercados de Santafé, y de los puertos fluviales de Honda y Mompox sobre el Magdalena. También la ciudad de Cartagena, las minas de plata del Tolima y las de oro en Antioquia. En la segunda mitad del siglo XVII empezaron a aparecer una serie de factores que afectaron el uso de la tierra y produjeron un descenso en la producción agropecuaria. El traspaso de propiedades a la Iglesia, la escasez de mano de obra y la aparición de la enfermedad del polvillo que afectó la producción de trigo, fueron algunos de ellos. Pero lo que produjo el colapso de la producción de trigo fue la decadencia de los mercados mineros, y del mercado de Cartagena. Las minas de plata fueron cerradas una tras otra durante el siglo XVII a causa de su inadecuada explotación, escasez de mano de obra y la dependencia del mercurio, que muchas veces se retrasaba en llegar. El mercado minero también decayó para las haciendas sabaneras por el contrabando, y por los comerciantes ambulantes que trasladaban mercancías y productos alimenticios. Igualmente se registró un aumento del consumo de maíz y la presencia de abastecedores

41 Juan A. Villamarín, "Haciendas en la Sabana de Bogotá, en la época colonial: 1539-1810", Enrique Florescano (ed.), Haciendas, Latifundios y Plantaciones en América Latina, México, Siglo XXI, 1975 pp. $327-345$

${ }^{42}$ Entre las propiedades rurales, relacionadas en el Anexo 1 de la tesis en curso, se encuentran la estancia de tierras y hato en el pueblo de la Serrezuela, de doña Catalina Bravo; la estancia de pan y el trapiche que lindaban con la Mesa de Juan Díaz, de Martín de Nava y Juana García su mujer; una estancia en el valle de Chinga, del Capitán Juan D. Antonio de Orjuela; una estancia de pan y ganado mayor en tierras del valle de Usme, del Capitán Francisco Santo Negrón y Julio Esteban Franqui; la Dehesa de Bogotá con un censo a nombre de don Femando Leonel Caicedo y doña Francisca Ramírez Maldonado, dos estancias de pan y ganado menor, en el valle de Fucha, de Juan Bohórquez Forero, una estancia de pan y ganado menor en Chocontá, de Balthazar Cabral de Melo, una estancia en el valle de Tunjuelo llamada Tolosa, de Diego Forero, etc. 


\section{GRAFICA 1. PRINCIPALES DE CENSOS PRESTADOS POR EL CONVENTO DE SANTA CLARA DE SANTAFE DE BOGOTA DURANTE ELS. XVII}

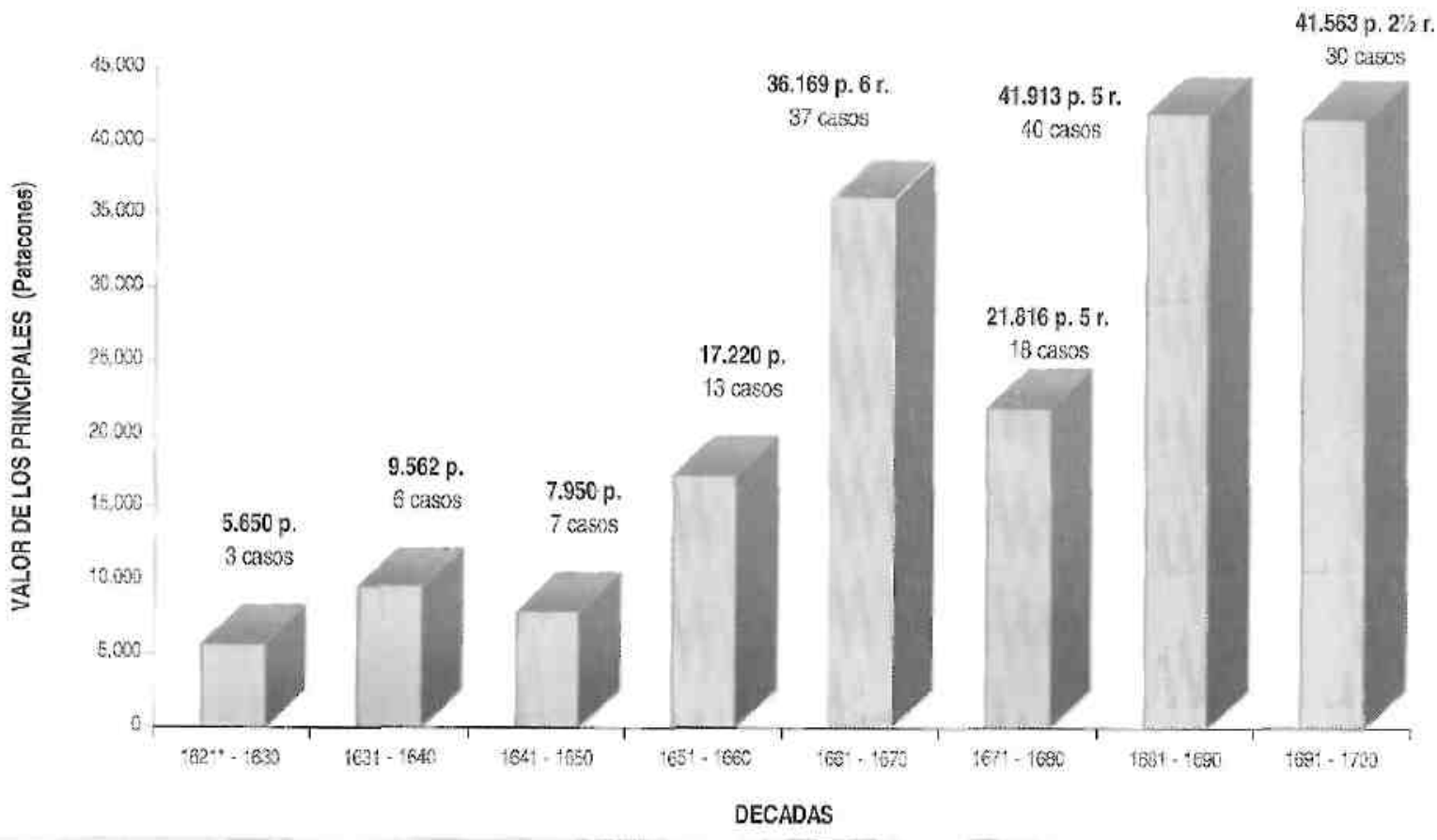

p.: patacones $r$,: reales q.: cuartillos Valor total de los principales prestados por el

Convento: 124.740 patacones $1 / 2$ real y 1 cuartillo

Número total de casos de ia muestra: 108 
de trigo geográficamente más cercanos a las minas. Cartagena comenzó a recibir trigo de Norteamérica a principios del siglo XVIII y continuó recibiendo, con esclavos y contrabando, hasta finales de la colonia. Problemas en el transporte desde la Sabana hasta el puerto costero, e intereses creados en la ciudad fortificada que operaba comercialmente más en términos del Caribe y de los ingleses, que de la Nueva Granada, produjeron el cierre de este mercado. ${ }^{43}$ La ciudad de Santafé tuvo una importancia secundaria para los productores de trigo, ya que durante gran parte del siglo XVII estuvo bajo el control de precios, control que afectó también a la ganadería.

Al observar la gráfica de Principales de censos otorgados durante el siglo XVIII, vemos que en las primeras décadas de éste siglo, como en las últimas del XVII, el convento de Santa Clara siguió adjudicando los altos volúmenes de principales. De acuerdo con Villamarín, ${ }^{44}$ a mediados del XVIII la producción de las haciendas ya había decaído y sus productos se destinaban al consumo interno y a los mercados restringidos de la región y de la ciudad. Los hacendados descendientes de encomenderos, y otros que habían adquirido tierras de extensión, buscaron afianzarse en cargos burocráticos y se trasladaron a la actividad comercial, como complemento al producido de las haciendas. Sin embargo, la falta de capital afectó tanto a hacendados como a comerciantes y burócratas. Los créditos otorgados por los conventos seguían siendo en el XVIII, una opción económica.

La información arrojada por los censos fue analizada a la luz de la conceptua-lización de Bauer, ${ }^{45}$ Teruel Gregorio de Tejada ${ }^{46}$ y Ferreira, ${ }^{47}$ para ello se elaboraron doce clases de censos y se introdujo el concepto de censo "ad honestum lucrum"(sin respaldo de ningún bien raíz), presente en algunos documentos.

$43 \quad$ Ibid, pp. 338 - 340.

$44 \quad$ Ibid, pp. 339 - 340.

${ }^{45}$ A. J. Bauer, "La Iglesia en la economía de América Latina, siglos XVI al XIX", A.J. Bauer (comp.), La iglesia en la economía, pp. 27-43.

46 Manuel Teruel Gregorio de Tejada, Vocabulario básico, pp. 440 - 442.

47 Carmen Adriana Ferreira Esparza, Censos y Capellanías. El crédito en la Provincia de Pamplona. 1700 1760, tesis de Grado para optar el título de Historiador, Bucaramanga, U.I.S., 1993; "Capellanías y Censos: una conceptualización necesaria para el estudio del crédito colonial", Ensayos de Historia Regional, Bucaramanga, U.I.S., 1995; "La iglesia y el crédito colonial. Pamplona, Nuevo Reino de Granada, 17001760", Revista innovar, Universidad Nacional de Colombia, enero-junio 1996; "El crédito colonial en la provincia de Pamplona: usos del censo consignativo. Siglo XVIII", Revista de Humanidades, Bucaramanga, U.I.S., vol. 26, No. 1, enero-junio de 1997. 


\section{GRAFICA 2. PRINCIPALES DE CENSOS PRESTADOS POR EL CONVENTO DE SANTA CLARA DE SANTAFE DURANTE EL S. XVIII}

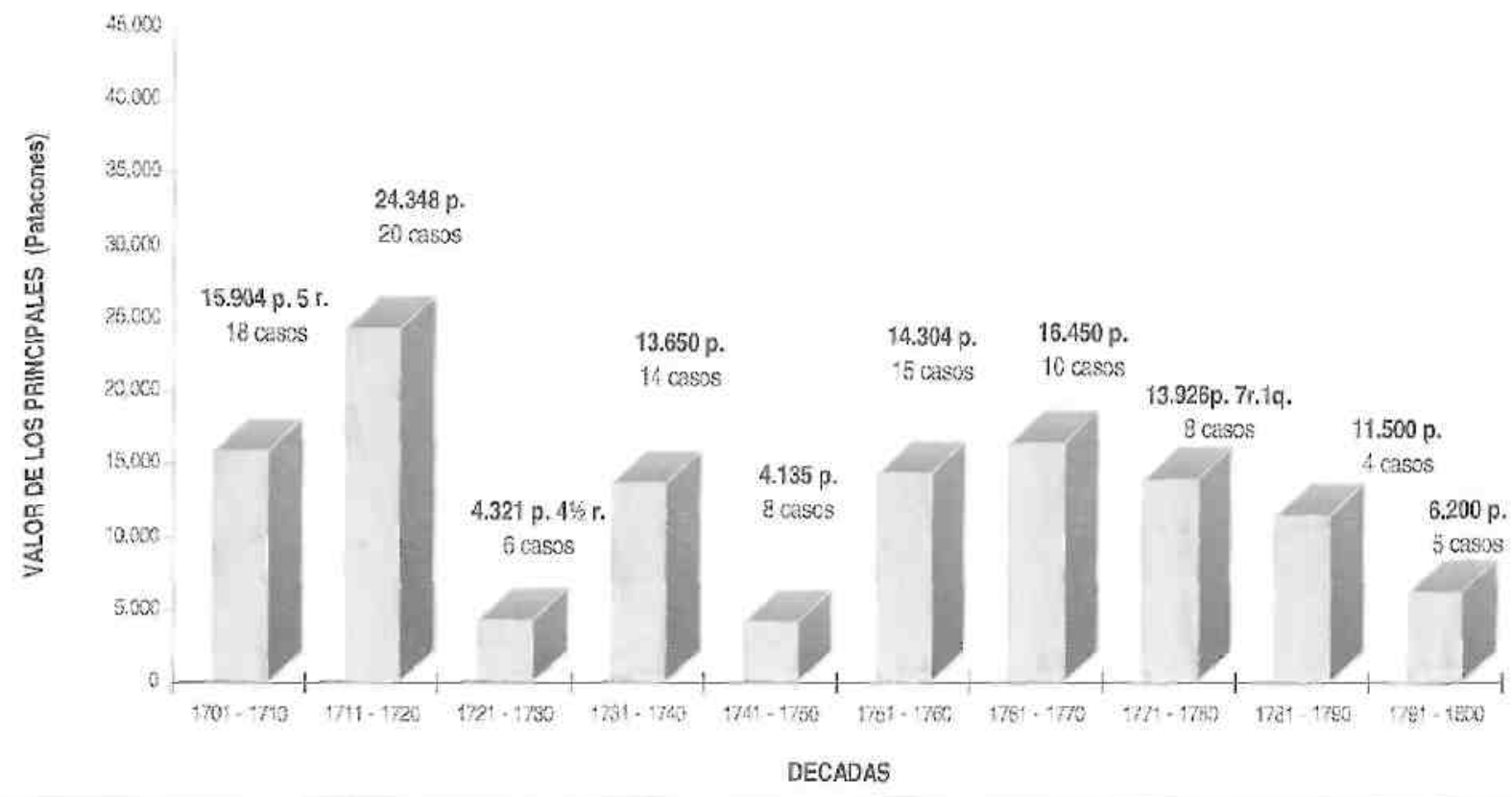

p.: patacones r.: reales Valor total de los

principales prestados por el Convento: Número total de 181.845 patacones $2 \frac{1}{2}$ reales. casos de la muestra: 154. 
El primer lugar lo ocuparon los censos del tipo "censo préstamo consignativo pecuniario", durante los dos siglos. Durante el XVII fueron perpetuos, mientras que en el siglo XVIII temporales. Esto quiere decir que las religiosas otorgaron directamente dinero a préstamo (consignativo), cuyos réditos exigieron pagar en efectivo (pecuniario), pero que mientras en el siglo XVII no se fijaba un plazo para redimirlos, en el XVIII sí se precisaba. En segundo lugar el censo gravamen ${ }^{48}$ pecuniario perpetuo fue el más solicitado, pero en el XVIII el número de casos superó notoriamente los del XVII. Después del préstamo de dinero en efectivo, la segunda función económica más importante del convento durante el periodo analizado, fue financiar la adquisición de bienes raíces, al poner en movimiento la circulación de inmuebles que le habían sido gravados, pero que por uno u otro motivo, el gravamen no había sido redimido. El nuevo dueño del bien lo adquiría sin pagar grandes sumas. A cambio se hacía cargo del pago de los réditos. El bien podía ser gravado por herencia, traspaso, compra en remate, deuda del cónyuge, entre otras. El mayor movimiento de censos gravados durante el siglo XVIII se entiende al constatar que el convento ya llevaba al comenzar dicho siglo, 72 años de actividad crediticia.

\section{Las dotes}

Los ingresos de las dotes, exceptuando las de las fundadoras beneficiadas por la obra pía del fundador y patrono monseñor Arias de Ugarte y los cupos dejados por la muerte de las beneficiadas, provinieron generalmente de los progenitores. Cuando esto no ocurría porque las novicias eran huérfanas o sus padres pobres, la suma la pagaba otro familiar. Estas doncellas podían beneficiarse de la obra pía del patrón, o por la limosna de alguna viuda acaudalada, o un jerarca de la iglesia metropolitana. ${ }^{49}$

La dote era pagada de diferentes maneras: censos, herencias, obras pías, capellanías, limosnas, o simplemente de contado. El valor más alto correspondía a las dotes de las religiosas de velo negro, dos mil patacones, el más

\footnotetext{
48 Carmen Adriana Ferreira Esparza, Censos y Capellanías, p. 108 "Esta modalidad de censo se tipificaba cuando se adquiría un bien que había sido hipotecado con anterioridad, para sustentar uno o varios censos, que no habían sido redimidos. Un censo gravamen se podía adquirir mediante la compra-venta, compra en remate, traspaso o por recibir como herencia dicho bien. También las fundaciones de capellanías censuadas y los reconocimientos de dotes de monjas se hacían mediante ésta modalidad de censo."

49 A.G.N. (Santafé de Bogotá), Conventos, t. 67, ff. 645r - 688v.
} 
bajo a las de velo blanco, que oscilaba entre 1000 y 300 p. cuando la novicia servía para algún oficio, como encargarse de la botica o tocar un instrumento musical. Con algunas excepciones los responsables de las novicias pagaron o dieron en garantía de pago bienes inmuebles o personas útiles para el trabajo. En 1677, la dote de Francisca de San Miguel, monja lega de velo blanco, fue pagada con un órgano para el convento, ${ }^{50}$ en 1688 como garantía de pago por la dote de la religiosa de velo negro Beatriz de San Vicente, su padre el capitán Cristóbal Cortés de Vasconcelos, dejó en depósito dos "esclavos para servir al convento". ${ }^{51}$

Según lo estipulado en la décima cláusula de la escritura de fundación del convento, ${ }^{52}$ las primeras 24 dotes deberían ser donadas por los fundadores. Los Arias de Ugarte expresaban su voluntad para que se recibieran "sin Dote, ni Ajuar alguno", máximo 24 religiosas, "naturales de esta Ciudad, y de las demás ciudades, y Villas de este dho. Nuevo Reyno[...j". ${ }^{3}$ Pero en el "Libro de las licencias para entrar religiosas en el convento de Santa Clara", ${ }^{54}$ se encuentra que sólo doce fueron favorecidas con lo estipulado por el fundador.

La gran diferencia entre la cantidad de dinero recogida por concepto de dotes de velo negro y de velo blanco, 231.000 p. contra 23.056 p., en el periodo de 1644 a 1734, evidencia el papel económicamente secundario de las dotes de velo blanco, pero resalta la importancia social del convento, como lugar de refugio no sólo para las doncellas de la elite, sino para las de menor status económico y social. Al comparar las cifras de ingresos de religiosas en el siglo XVII con las del XVIII, y teniendo en cuenta que la muestra del XVII es más grande que la del XVIII, se observa, guardadas las proporciones, una menor cantidad de profesión de religiosas y de casos gravados por dote durante el último siglo. Esto significa un descenso en la necesidad de recurrir a censos para ingresar las doncellas al convento. ¿Poiqué? Es posible que debido al proceso de mestizaje existiera menos presión

50 A.G.N. (Santafé de Bogotá), Conventos, t. 67, f. 690v.

51 A.G.N. (Santafé de Bogotá), Conventos, t. 65, ff. 421 r - 426v.

A.C.S.C. (Santafé de Bogotá), Copia manuscrita de los registros y protocolos en los que consta la fundación original del Convento, Santa Fe, enero 7 de 1792.

53 Ibid, (s.f) f. 10. La foliación es mía.

54 A.G.N. (Santafé de Bogotá), Conventos, t. 67, f. 621r-v. 
social para ingresar a las mujeres al convento, ya que probablemente podían conseguir marido fuera de los estrechos círculos marcados por la limpieza de sangre.

\section{Los recursos de la fe: las capellanías y las obras pías}

En aquellos tiempos los creyentes podían expiar las culpas para acceder a la salvación del alma a través de las capellanías ${ }^{55}$ y de las obras pías.

Según el diccionario de Vocabulario básico para la Historia de la Iglesia las capellanías

"son fundaciones perpetuas por las que una persona segregaba de su patrimonio ciertos bienes (en vida o por testamento) y formaba con ellos un vínculo, [...] destinado a la manutención [...] de un clérigo, que se obligaba por ello a celebrar [...1 cierto número de misas por el alma del fundador, o de su familia, y a cumplir otras cargas litúrgicas. El hecho de que estas funciones se realizasen en una capilla explica su denominación" 56

La primera capellanía del convento fue la capellanía eclesiástica familiar, que figura en su escritura de fundación. ${ }^{57}$ Allí se nombraba y asignaba el sueldo de un capellán, que celebraría la misa diaria, y administraría a las monjas los santos sacramentos. Los domingos y días de fiesta, las misas serían cantadas, y rezadas. Entre semana se oficiarían por "los Reyes Nuestros Señores Felipe Segundo Tercero, y quarto [...] y por las perzonas quien se tocan en parentezco [...], y por las [...1 Religiosas[.]" A la muerte del capellán el patrón nombraría a un sacerdote virtuoso y cercano al linaje de los Arias de Ugarte, en caso de no haberlo, el cargo recaería en otro clérigo de Santa Fe o del reino. De la renta de los 40 mil p. que producirían anual-

\footnotetext{
${ }^{55}$ Capellanía (De capellán): fundación en la cual ciertos bienes quedan sujetos al cumplimiento de misas y otras cargas pías. Diccionario de la Real Academia de la Lengua Española. En adelante citado como D.R.A.E., Madrid, Espasa - Calpe, 1982, vol. II, p. 253. Ver: Carmen Adriana Ferreira Esparza, Censos y Capellanías, p. 11-35. La autora define y recuerda su origen, citando a Philipe Aries, El hombre ante la muerte, Madrid, Taurus, 1984, p. 149. Aparecen a partir del s. XII, cuando se produce un marcado cambio en los rituales funerarios y la muerte se convierte en ocasión de misas.

${ }^{56}$ Manuel Teruel Gregorio de Tejada, Vocabulario básico, p. 63.

${ }^{57}$ A.CS.C (Santafé de Bogotá), Copia manuscrita, (s.f.) (la foliación es mía), f. 17.
} 
mente dos mil p., se le pagarían 250p. anuales. ${ }^{58}$ En 1663, María Arias de Ugarte otorgó testamentariamente una capellanía sobre las casas que tenía en la plaza de Santafé. Figuraba también la fundación de una segunda capellanía sobre otras casas viejas que tenía en el mismo lugar. ${ }^{59}$ Se observa su carácter claramente laical, cuando doña María solicitó que, al morir, el capellán fuera remplazado sin intromisión de otras autoridades eclesiásticas, prefiriendo los de su linaje. ${ }^{60}$ En cuanto a la primera capellanía, dejaba las casas nuevas de la plaza a su marido, y a la muerte de éste, pedía que se entregaran dos capellanías. Los capellanes tendrían la obligación de decir misa en el Convento, con diácono, los días de la Conversión de San Pablo, de San Francisco, de San Gerónimo, de Santa Isabel, de San Diego, de San Juan Bautista, y de San Joseph. El estipendio fijado era de tres p. por misas cantadas y uno por misa rezada. Los arriendos de las casas, calculados en 200 p. los repartiría el patrón entre los capellanes. En la segunda capellanía de 2.600 pesos sobre las casas viejas de la plaza, nombraba por primer capellán al bachiller Juan de Novoa Sotelo, clérigo presbítero, a quien ella había criado como a su hijo, y a quien le mandaba cantar misas en los días de Santa Clara, de San Joseph, de la "Conmemoración de su propia muerte", de San Roque, del San Nicolás de Tolentino, ${ }^{61}$ y otra misa cantada por el Ángel de la Guarda, con diácono y subdiácono. Las misas se harían por las almas de ella, su marido, sus parientes ${ }^{62}$ y las de Francisco de Novoa Maldonado, ${ }^{63}$ las religiosas del Convento, especialmente por sus tías Damiana de San Francisco, y Agustina de Ugarte. Y de sus primas Juana de Cristo, Isabel de la Trinidad, Ana de San Francisco y Melchora de la Ascensión. También por el Padre Juan Cotrina, ${ }^{64}$ por los indios e indias de su encomienda y por los negros que la han servido. El beneficio sólo cubriría a los de su encomienda. Tendrían que confesar a las religiosas el día de la regla. Como patrones fueron nombrados la abadesa, su marido, y

\footnotetext{
${ }^{58}$ Ibid, (s.f.) f. 15.

${ }^{59}$ A.G.N. (Santafé de Bogotá), Conventos, t. 65, ff. 792r - 803r.

${ }^{60}$ A.G.N. (Santafé de Bogotá), Conventos, t. 65, f. 794r.

61 San Nicolás de Tolentino, como los otros santos fueron pintados unos por Gaspar de Figueroa, otros por Gregorio Vásquez, y otros por anónimos del siglo XVII, quizá por encargo de doña María, para poblar las paredes de la iglesia del convento de Santa Clara. Hoy forman parte del inventario iconográfico de la Iglesia Museo.

${ }^{62}$ Especialmente su tío, el ilustrísimo don Fernando de Ugarte, fundador y patrono del convento de Santa Clara.

63 Posiblemente su primer marido, del que quedó viuda.

64 "El sueño del Bachiller Cotrina", Gregorio Vásquez, óleo sobre tela, 1668. Pintura de la Iglesia de Santa Clara.
} 
el Padre Rector de la Compañía de Jesús, a quienes asignó la renta de una tienda.

Esta capellanía laical, ${ }^{65}$ una de las más importantes del monasterio por haber sido fundada por la patrona, recorrió la historia del convento desde el siglo XVII hasta el XIX. Dos documentos del siglo XIX, uno de $1842,{ }^{66}$ y otro de $1848^{67}$ el cual tiene una nota otorgando el mismo cargo de capellán en 1858 a otro religioso, atestiguan el funcionamiento activo de éstas capellanías hasta la segunda mitad del siglo.

La obra pía siguiendo la definición que Manuel Teruel Gregorio de Tejada ${ }^{68}$ hace de legados píos es una porción de rentas asignada a una obra de piedad o de beneficencia, e inclusive a una capellanía. Carmen A. Ferreira las define como "fundaciones cuya finalidad era el sostenimiento material de las instituciones religiosas o de beneficencia como conventos, hospitales, iglesias, y el sostenimiento del culto y las fiestas religiosas [...]". Como ya lo vimos, la fundación del convento fue producto de una obra pía. En adelante, su devenir económico estuvo salpicado por una que otra, la mayoría de ellas ordenadas en un acto testamentario. Las más importantes obras pías fueron fundadas por miembros activos de la jerarquía eclesiástica del arzobispado de Santafé.

\section{Las herencias y donaciones}

En sólo un caso el heredero fue el convento, en los demás lo fueron las clarisas. El convento heredó un censo para adelantar la obra de la iglesia, las religiosas heredaron algunos problemas cuando recibían censos sin redimir, y con réditos atrasados, otras recibieron bienes de capellanías, haciendas y trapiches gravados con censos y el remate de algunos bienes.

65 Manuel Teruel Gregorio de Tejada, Vocabulario básico, p. 63. Las capellanías "laicales o mercenarias, instituidas sin intervención directa del ordinario, aunque con su aceptación y con el cuidado de velar por el cumplimiento de las cargas espirituales impuestas por el fundador."

${ }^{66}$ A.C.S.C. (Santafé de Bogotá), Hoja suelta. Nombramiento como capellán de la cuarta capellanía de Da. María Arias de Ugarte a Don Esteban Esturau, por parte de la abadesa María del Carmen de San Antonio, 10 de noviembre de 1842, lf.

${ }^{67}$ Nombramiento como capellán de la tercera capellanía de Da. María Arias de Ugarte al P. Mateo Díaz de la Orden de los Predicadores, por parte de la abadesa María del Carmen de San Antonio, 10 de septiembre de 1848, lf.

${ }^{68}$ Manuel Teruel Gregorio de Tejada, Vocabulario básico, p. 63. 


\section{Los egresos: un pasadizo a la clausura}

Los gastos que el convento tuvo entre 1661 y $1760^{69}$ fueron clasificados en tres clases, de manutención, religiosos y varios. Los más elevados fueron los de manutención en primer lugar con cerca de 84 mil patacones y los religiosos en segundo lugar con 38.129 p. Dentro del rubro de manutención el mayor gasto corrió por cuenta de la carne, con 14.287 p., mientras que en los gastos religiosos, la compra de objetos litúrgicos de plata con 14.234 p. y las fiestas religiosas, con 13.425 p. representaron los volúmenes más altos. Los gastos varios, entre los que se encuentran gastos de servicios, utensilios para la cocina y mejoras sumaron cerca de 38 mil patacones.

Dentro de los gastos de manutención, lo que más costó a las clarisas fue la alimentación. Las erogaciones semanales incluían compras de trigo, pan, maíz, turmas, leche, huevos, manteca, sal y leña. También anotaban los consumos en "alhajas" de la cocina, ${ }^{70}$ los gastos de los viernes, ${ }^{71}$ la cera, el vino y las hostias de la sacristía, lámparas y macetas. En casi todas las cuentas aparecen relacionados desembolsos por la fiesta de Santa Clara. Las cantidades de carne compradas por el convento muestran el alto consumo de carnero y vaca dentro de la comunidad. En $1759,{ }^{72}$ fueron sacrificados una vaca y un carnero durante la fiesta de Santa Clara. Entre $1682-1684,{ }^{73}$ las religiosas gastaron $2.296 \mathrm{p}$. en carne de vaca y de carnero $^{74}$ para el monasterio, 296 p. más que el alto valor de una dote de velo negro. Los

${ }^{69}$ A.G.N. (Santafé de Bogotá), Conventos, t. 77, ff. 768r - 864 v; Conventos, t. 63, ff. 48r - 56v; Conventos, t. 67, ff. 733r - 936v; Conventos, t. 65, ff. 752r - 777v; Conventos, t. 46, ff. 233r - 248v; Conventos, t. 27, ff. 757r 790v; Conventos, t. 46, ff. 285r - 299v; Conventos, t. 76, ff. Ir - 23v; Conventos, t. 67, ff. 279r - 294v; Conventos, t. 58, 939r - 954v; Conventos, t. 76, ff. 38r - 57v; Conventos, t. 67, ff. 259r - 273v; Conventos, t. 67, ff. 569r - 584v; Conventos, t. 67, ff. 585 - 600r.

${ }^{70}$ A.G.N. (Santafé de Bogotá), Convenios, t. 77, ff. 768r - 864v. En la relación jurada del contador Pedroso, (1661 -1664), se observa bajo el renglón de gastos llamados "Otras Cosas", que el valor de una olla de cobre de 2 arrobas y 6 libras, (a 2p.), era de 112 p.

${ }^{71}$ Los viernes eran días especiales para las compras y pagos. Al parecer ese día había venta de carne y mercado en Santafé.

72 A.G.N. (Santafé de Bogotá), Conventos, t. 67, ff. 585 - 600r.

${ }^{73}$ A.G.N. (Santafé de Bogotá), Conventos, t. 63, ff. 48r - 56v.

${ }^{74}$ A.G.N. (Santafé de Bogotá), Conventos, t. 63, ff. 48r - 56v. El precio de ciertas cosas en la época de ésta cuenta, pueden dar una mejor idea de las proporciones de los valores mencionados. El gasto ordinario de cada semana, 63 p. por 119 semanas, 7.497 p., 12 carneros a la semana, 892 p. y 4r., 53 arrobas de vaca semanales, durante 119 semanas, descontando dos cuaresmas, 1404 p., 12 botijas de miel al año, costaron 48 p., 10 arrobas de cera en 2 años, 346 p. 2 r., manojos de vela para dos años, 446 p. 2 r. 
salarios representaron otro importante gasto para el convento. En las diferentes cuentas, se observa la variedad de empleados que necesitaban las monjas, quienes no podían realizar ciertos oficios, y por la clausura tenían que hacer diversos encargos. En 1664, el contador Pedroso ${ }^{75}$ relaciona los siete salarios más constantes en adelante: el del síndico, capellán, sacristán, barbero, médico, letrado y procurador. Los salarios más altos corresponden al síndico, 1.200 p., y al capellán, mil patacones por trienio.

Surtir la botica con recetas traídas del hospital San Juan de Dios y de la Compañía de Jesús, según uso y costumbre ${ }^{76}$ de los médicos de las clarisas, ocasionó un gasto constante. Compraron miel ${ }^{77}$ a las enfermas, que no eran sólo las religiosas sino también las cantoras y criadas del convento. ${ }^{78}$ Los valores de las recetas nunca fueron sumados dentro de los gastos de la botica y tampoco se totalizaron dentro de la data o gastos generales. Esto hace pensar en la posibilidad de que hubiesen sido pagadas con el dinero de alguna limosna o de alguna obra pía.

Los egresos por las mejoras del monasterio marcan, junto con los gastos en plata y los ocasionados por las estancias, los rubros más inestables. Las mayores mejoras durante la administración de una abadesa fueron las que llevó a cabo Gerónima de Jesús en $1729 .{ }^{79}$ Durante su trienio gastó 781 p. El valor más alto correspondió a un monumento de madera y lienzo pintado que compró por 300 p. Contrasta ésta suma con los 30 p. de la construcción de la casa pequeña levantada en la huerta, para la hortelana.

Las clarisas sólo poseyeron estancias durante la segunda mitad del siglo $\mathrm{XVII},{ }^{80}$ que como ya lo anotamos fue uno de los periodos más críticos de la economía agrícola de las haciendas de la Sabana. Entre 1661 y 1664, el mayor gasto de la estancia de Usaquén fue el salario y la comida del mayordomo.

75 A.G.N. (Santafé de Bogotá), Conventos, t. 77, ff. 768r - 864v.

76 A.G.N. (Santafé de Bogotá). Conventos, t. 65, ff. 752r - 777v.

7 A.G.N. (Santafé de Bogotá), Conventos, t. 63, ff. 48r - 56v.

78 A.G.N. (Santafé de Bogotá), Conventos, t. 46, ff. 286r - 299v.

70 A.G..N.(Santafé de Bogotá), Conventos, t. 65, ff. 752r - 777v.

80 A.G.N. (Santafé de Bogotá), Conventos, t. 77, ff. 768r - 864v; Conventos, t. 63, ff. 48r - 56v. Conventos, t. 67, ff. $733-936 v$. 


\section{Las fiestas religiosas: luz, música y altares, las lecciones, lamentaciones y funerales}

Conmemoraciones de alegría marcadas en el calendario litúrgico, como la navidad, y la pascua, o de dolor como la Semana Santa, fueron las dos caras de la moneda festiva monacal. La cera era una materia básica para las celebraciones. Entre 1661 y 1664 el convento compró 19 libras de cera para la fiesta de la Virgen de la Candelaria. ${ }^{81}$ En la mayoría de las cuentas ${ }^{82}$ figura la compra de cinco arrobas y 14 libras de cera anuales. Este combustible además de ayudar a las religiosas a disipar las tinieblas de sus claustros en el anochecer y hacia el alba, les alegraba el espíritu en las noches festivas. Entre 1687 y $1690^{83}$ contrataron fuegos para la fiesta de Santa Clara. El cirio del patrón fue otra luz que encenderla ocasionó gastos. ${ }^{84}$ Desde 1725 se observan gastos en música de cuerdas y cañuelas para la Navidad, Semana Santa, la fiesta de Santa Clara, la de Ntra. Señora de la Soledad y la del "Glorioso San Antonio de Padua". Desde la cuarta década del siglo XVIII comienzan a ser adornadas las fiestas con flautas. Entre 1742 y 1743, contrataron cantoras religiosas ${ }^{85}$ y seglares ${ }^{86}$ cuyo pago constituyó uno de los valores más altos de las festividades, $2.336 \mathrm{p}$.

El ayuno del Adviento, la Cuaresma y las lecciones y lamentaciones de la Semana Santa, también causaron erogaciones. Generaron gastos las misas dominicales, ${ }^{87}$ el altar del Corpus construido en la plaza principal el día del Corpus, las fiesta "del patrocinio" ${ }^{88}$ de la Concepción y de la Encarnación. Dos celebraciones, Navidad y Cuaresma, fueron los valores más constantes $\mathrm{y}$ altos pagados por el convento en fiestas religiosas.

${ }^{81}$ A.G.N. (Santafé de Bogotá), Conventos, t. 77, ff. 768r - 864v.

${ }^{82}$ A.G.N. (Santafé de Bogotá), Conventos, t. 46, ff. 233r - 248v; Conventos, t. 27, ff. 757r - 790v; Conventos, t. 46, ff. 285r - 299v; Conventos, t. 76, ff. Ir - 23v; Conventos, t. 67, ff. 279r - 294v; 954v: Conventos, t. 76, ff. 38r - 57v; Conventos, t. 58, 939r - 954v; Conventos, t. 67, ff. 259r - 273v; Conventos, t. 67, ff. 569r -584v; Conventos, t. 67, ff. 585r - 600r.

83 A.G.N. (Santafé de Bogotá), Conventos, t. 67, ff. 733r - 936v.

${ }^{84}$ A.G.N. (Santafé de Bogotá), Conventos, t. 67, ff. 733r - 936v.

${ }^{85}$ A.G.N. (Santafé de Bogotá), Conventos, t. 65, ff. 752r - 777v.

${ }^{86}$ A.G.N. (Santafé de Bogotá), Conventos, t. 67, ff. 259r - 273v, Conventos, t. 58, ff. 939r - 954v.

${ }^{87}$ A.G.N. (Santafé de Bogotá), Conventos, t. 65, ff. 752r - 777v.

${ }^{88}$ A.G.N.(Santafé de Bogotá), Conventos, t. 67, ff. 279r - 294v, Conventos, l. 58, ff. 939r - 954v. Posiblemente es la fiesta del aniversario de la muerte del patrón. 
Los funerales de los cofrades del Divino Amor aparecen relacionados a partir de $1725 .{ }^{89}$ Entre 1736 y 1743 figuran, además de los anteriores, los de San Bernardo. ${ }^{90}$ En 1752 comienzan a registrarse las exequias de los hermanos del Arcángel San Miguel, y en 1760 las de los hermanos de la octava del Corpus.

En 1664, ${ }^{91}$ el convento pagó por el entierro de Juana de Jesús cien p., más las honras fúnebres que sumaron 39 p. y $1 \frac{1}{2} \mathrm{y}$ el novenario de misas que costó cuatro p. y cuatro reales, en total 144 p. Entre 1759 y $1760^{92}$ el entierro de una religiosa de velo negro costaba 150 p., el de una de velo blanco cincuenta p., y el de una criada tan sólo seis p. En éstos rituales se observan las grandes diferencias económicas entre los tres grupos de mujeres que habitaron el convento. El entierro de una religiosa de velo negro triplicaba el valor y la significación social, religiosa y el staus, de una de velo blanco.

Las religiosas de velo negro al morir dejaban las limosnas que otorgaban al convento para sus hermanas. Los sábados repartían 208 p..$^{93}$ entre las religiosas más pobres, enfermas y necesitadas. Los lunes el convento distribuía la limosna del pan, es de suponer que entre los vecinos pobres de la ciudad.

Los gastos varios del monasterio incluyen aseo, sacristía, incienso, velas para uso diario, aliños del convento, vestuario de las religiosas y de las criadas, hasta el pago de monjas y seglares cantoras, de bulas, pleitos y negocios, de las escuelas de las señoras Pastrana, y gastos excepcionales como los de $1743,{ }^{94}$ ocasionados por las reparaciones de los daños causados por un temblor de tierra. Entre 1687-1690, ${ }^{95}$ hay pagos que tienen que ver con la terminación de la Iglesia del convento, como la compra de tachuelas, o la de unas libras de oro para las ventanas y el techo, además del pago al dorador que pintó la cenefa del templo. Curiosamente es la única ocasión en la que aparecen unos

\footnotetext{
${ }^{89}$ A.G.N. (Santafé de Bogotá), Conventos, t. 46, ff. 233r - 248v.

${ }^{90}$ A.G.N. (Santafé de Bogotá), Conventos, t. 76, ff. 1 r - 23v; Conventos, t. 67, ff. 279r - 294v; Conventos, t. 58, ff. 939r - 954v; Conventos, t. 76, ff. 38r - 57v; Conventos, t. 67, ff. 259r - 273v.

91 A.G.N. (Santafé de Bogotá), Conventos, t. 77, ff. 768r - 864v.

92 A.G.N. (Santafé de Bogotá), Conventos, t. 67, ff. 585r - 600v.

93 A.G.N. (Santafé de Bogotá), Conventos, t. 67, ff. 279r - 294v.

94 A.G.N. (Santafé de Bogotá), Conventos, t. 67, 259 - 273v.

95 A.G.N. (Santafé de Bogotá), Conventos, t. 67, ff. 733r - 936v.
} 
"fuegos" ofrecidos en la fiesta de Santa Clara, que posiblemente se encendieron también por la inauguración de la iglesia.

El gasto en las escuelas de las señoras Pastrana, anotado entre 1737-1738, ${ }^{96}$ aparecerá en adelante constantemente. Allí se registra también, el "embovedado del ejercicio", la obra del patio cubierto, la nueva cañería, y el enladrillado de los claustros. En 1752, la abadesa Josepha de San Ignacio mandó pintar el coro, las oficinas y ayudó en el vestuario de las religiosas y seglares cantoras. Los vestidos costaron la elevada suma de 2.570 p., el precio de una casa mediana en el centro de la ciudad. En este año los gastos se dispararon hasta 4.033 p., el valor más alto por gastos varios dentro de una cuenta anual. El ascenso se debió al pago de las cantoras, y de la pintura que decoró el coro, ${ }^{97}$ la cual causó una gran erogación.

\section{Los bienes}

El convento percibió ingresos de sus estancias y bienes urbanos. Estos bienes fueron adquiridos por las clarisas de diversas maneras. Los de la fundación fueron otorgados como obra pía por el arzobispo Arias de Ugarte, sus familiares y descendientes. Los demás fueron adquiridos a través de remates por incumplimiento en el pago de réditos de los censos, y por legados de herencias, capellanías y otras obras pías. El convento también contó con bienes de capital cuyas sumas eran recaudadas en especial de los pagos de las dotes, de los réditos y de la redención de los principales. El dinero de las monjas fue administrado por el convento, pero según se tratara de su procedencia, -herencia, capellanía u obra pía- las ganancias por él generadas iban a parar a un fondo común o a una religiosa particular

\section{Los bienes urbanos}

La primera posesión que tuvo el convento de Santa Clara fueron las casas compradas para su edificación por el arzobispo Fernando Arias de Ugarte, "a don Luis Enriquez de Monroy en seis mil pesos corrientes", según cons-

\footnotetext{
${ }^{96}$ A.G.N. (Santafé de Bogotá), Conventos, t. 67, ff. 279r - 294v.

97 Pilar Jaramillo de Zuleta, Jorge Mario Múnera, Marta Granados, Coro alto de Santa Clara, Bogotá, El Navegante, 1991. Este libro muestra detalladamente algunos fragmentos de la pintura mural del coro, preciosamente decorado.
} 
ta en el testamento del arzobispo. ${ }^{98}$ En 1635 se requirió una ampliación. La abadesa fundadora, Damiana de San Francisco, solicitó nombrar "avaluadores para los cuatro pares de casas que quedaban en la cuadra del convento" y pertenecían al encomendero de Remedios Gaspar de Borja, y a su esposa Gracia de Espeleta, a Juan Gaitán, a Pedro León de Castellanos, escribano real, y a Santos Gil". ${ }^{99}$ Se invirtieron además de los 6.OOOp. iniciales, 7.758 p. en la compra de las casas de la segunda etapa de ampliación del convento.

La mayoría de los bienes urbanos que generaron rentas al monasterio ${ }^{100}$ eran casas $^{101}$ y tiendas localizadas en las principales parroquias de Santafé. Las clarisas tuvieron una casa en la Calle Real, arrendada entre 1.25 p. $(1719-1720)^{102}$ y 1.50 p. (1751-1752) ${ }^{103}$ anuales. En la misma importante calle poseyeron entre 9 y 11 tiendas arrendadas por 178 p. (1719-1729) y 199 p. (1725-1726) ${ }^{104}$ al año. Llegaron a tener seis tiendas en la Plaza, por las que cobraban 151 p. anuales, cuatro de las cuales fueron cedidas en obra pía por doña María Arias de Ugarte para pagar las dotes de doncellas pobres y virtuosas, una casa en la parroquia de la Catedral, y otras casas en diferentes lugares de la ciudad. Tuvo también cuatro tiendas en la Calle Real de las Nieves, por las que entre 1719 y 1720 tan sólo recibió 18 p. y alcanzó a tener hasta cinco tiendas en la Veracruz por las que recibió entre lOp. 3r. (1738-1739) ${ }^{105}$ y 60 p. (1735-1736). ${ }^{106}$ En las cuentas de 1742,, ${ }^{107}$

${ }^{98}$ A.C.S.C. (Santafé de Bogotá), Copia manuscrita del Testamento de D. Femado Arias de Ugarte, Ciudad de los Reyes del Pirú, 30 de mayo de 1639, hecha el 7 de enero de 1792, f. 4r.

99 A.G.N. (Santafé de Bogotá), Conventos, t. 73, f. 883r.

${ }^{100}$ A.G.N. (Santafé de Bogotá) Conventos, t. 77, ff. 768r - 864v; Conventos, t. 63, ff. 48r - 56v; Conventos, t. 67, ff. 733r - 936v; Conventos, t. 65, ff. 749r - 777v; Conventos, t. 46, ff. 233r - 248v; Conventos, t. 27, ff. 757r 790v; Conventos, t. 46, ff. 285r - 299v; Conventos, t. 76, ff. Ir - 23v; Conventos, t. 67, ff. 279r - 294v; Conventos, t. 58, ff. 939r. - 954v; Conventos, t. 76, ff. 38r - 57v; Conventos, t. 67, ff. 259r - 273v; Conventos, t. 67, ff. 569r - 584v; Conventos, t. 67, ff. 585 - 600r.

101 Asunción Lavrin, "Conventos de monjas", pp. 208 - 209 "Las casas ofrecían a los conventos una forma cómoda de inversión. Las mismas estaban cerca de los conventos [...] Los mayordomos que cobraban los alquileres mantenían un contacto frecuente con las monjas. Los conventos tenían un control directo, pudiéndolas vender o reparar a gusto. La administración de casas no dejaba de ofrecer sus aspectos negati vos. El más frecuente era el pago irregular de las rentas por parte de los vecinos [...]."

III A.G.N. (Santafé de Bogotá), Conventos, i. 65, ff. 749r - 777v.

103 A.G.N. (Santafé de Bogotá), Conventos, t. 67, ff. 569r - 584v.

104 A.G.N. (Santafé de Bogotá), Conventos, t. 46, ff. 233r - 248v.

15 A.G.N. (Santafé de Bogotá), Conventos, t. 58, ff. 939r - 954v

106 A.G.N. (Santafé de Bogotá), Conventos, $t$ 76, ff. Ir - 23v. 
$1743,{ }^{108}$ y 1752, aparece que con éstos arriendos pagaron 4 salarios al procurador del convento. Las siete tiendas cedidas por María Luisa de Ospina, irrojaron desde $1734,{ }^{109}$ hasta la última cuenta estudiada de 1769 , ingresos entre 94p. y 153 p. anuales. Pero no solamente dentro del perímetro urbano de la ciudad de Santafé poseyó bienes el convento. En Honda le había quedado una casa con bodegas y tiendas que eran del Maestre de Campo Manuel Dineros, por las cuales recibió entre 60 p. (1728-1729) ${ }^{110}$ y 350 p. 11751-1752).

\section{Los bienes rurales}

Dentro de los bienes rurales del convento de Santa Clara encontramos, fuera de las estancias y haciendas censadas, propiedades en diferentes lugares de la Sabana de Bogotá: en Suba, Usaquen, y Techo, las cuales administró directamente en el siglo XVII. En el siglo XVIII posiblemente ya las había vendido, ${ }^{111}$ pues no aparecen registradas en los libros de cuentas.

En 1664, ${ }^{12}$ poseía dos estancias en "el pantano de la punta de Suba" que vendió a Diego de Agudelo, en 300 p. También tenía las "Tierras en Usaquén que fueron de Pedro de Urretaninzqui". El convento las remató "para redimir el censo que sobre ellas estava". El monasterio pagó ${ }^{113}$ una provisión real para que "diesen servicio los indios de Usaquén" en esta estancia. Sus frutos produjeron entre 1661 y 1664, 199 fanegadas de trigo, 1.112 unidades de queso, 150 unidades de mantequilla, cuatro fanegadas de turmas o papas, y seis fanegadas de maíz blanco podrido en la caña. Se observa que los gastos superaron a los ingresos, posiblemente por esto fue vendida. Las cuentas de Usaquén ejemplifican también la crisis de la producción agrícola en las haciendas de la Sabana durante éste periodo.

\footnotetext{
${ }^{107}$ A.G.N. (Santafé de Bogotá), Conventos, t. 76, ff. 38r - 57v. 108

A.G.N. (Santafé de Bogotá), Conventos, t. 67, ff. 259r - 273v. ${ }^{109}$

A.G.N. (Santafé de Bogotá), Conventos, t. 46, ff. 285r - 299v.

${ }^{110}$ A.G.N. (Santafé de Bogotá), Conventos, t. 27, ff. 757r - 790v.

${ }^{111}$ Asunción Lavrin, "Conventos de Monjas", p. 209. Similar a lo ocurrido en la Nueva Granada, sucedió en la Nueva España: "A diferencia de algunas órdenes masculinas, los conventos de religiosas capitalinas no demostraron gran interés en retener propiedades rurales durante el siglo XVIII [...]. En nuestro caso cabe recordar el de la Compañía de Jesús y sus haciendas agrícolas.

${ }^{112}$ A.G.N. (Santafé de Bogotá), Conventos, t. 77, ff. 768r - 864v.

113 A.G.N. (Santafé de Bogotá), Conventos, t. 77, f. 830r.
} 
Otra estancia del convento fue la de Techo, cedida por María Arias de Ugarte, como obra pía. Según lo había estipulado no se podía vender. Con sus frutos y rentas mandó celebrar "la fiesta del patriarca San Joseph y la fiesta de Nuestra Señora de la Concepción". El resto sería repartido entre las religiosas pobres y enfermas. Las cuentas de $1690^{\prime 4}$ permiten ver que la mayoría de lo producido por la estancia era para el consumo interno del convento. En 1692 fue vendida a Blas de Ochoa ${ }^{115}$ en cinco mil patacones que siguieron usando según la voluntad de la patrona.

\section{Los bienes de capital: los juros de la Real Caja y la Caja de Depósitos}

El dinero del convento fue guardado por lo menos en dos lugares claramente delimitados por los documentos: La Caja Real de Santafé y la Caja de depósitos del convento.

La Madre Inés de la Trinidad, abadesa del Convento de Santa Clara, solicitó en 1682 al Tribunal de la Real Audiencia, a través del escribano de Cámara, ${ }^{116}$ una certificación autenticada de lo que constaba en las cuentas y de los papeles traídos al Monasterio desde la Real Caja. De estas cuentas y papeles requería las cantidades que habían importado los réditos de los juros ${ }^{117}$ pagados en la Real Caja al Convento desde 1681, quienes habían dado los recibos de ellos, y el tiempo y la cantidad de cada recibo. Lo requería con toda claridad y distinción para que así constara en su comunidad.

En 1743, la abadesa Juana de la Trinidad ${ }^{118}$ se quejaba de no poder cumplir con la acostumbrada mejora del vestuario de las religiosas, hecha al finalizar el gobierno de cada abadesa, porque no tenía dinero por el atraso en las rentas

114 A.G.N. (Santafé de Bogotá), Conventos, t. 67, ff. 733r - 936v.

115 A.G.N. (Santafé de Bogotá), Conventos, t. 64, f. 442r.

116 A.G.N. (Santafé de Bogotá), Conventos, t. 23, ff. 2 a 5.

117 Germán, Colmenares, Historia económica, pp. 361 - 362: "El sistema entero de finanzas del reino reposaba en la existencia de Cajas reales, las cuales centralizaban los ingresos y los gastos. Para ser exactos, habría que hablar más de ingresos que de gastos. En materia de gastos las Cajas reales se limitaban a pagar el salario de los funcionarios reales más importantes [...]. Las Cajas reales estaban concebidas [durante el siglo XVI] como un receptáculo provisional del Tesoro real, el cual debería trasladarse a España lo más íntegramente que se pudiera. [...] Originalmente, el sistema financiero de las Cajas reales era bastante simple. En el curso del siglo XVII se fue complicando con la distinción entre "rentas ordinarias" y los gravámenes impuestos a finales del siglo XVI [...], se convirtieron en un verdadero drenaje de capitales con el sistema de juros, por los cuales la Corona debía satisfacer intereses regularmente."

118 A.G.N. (Santafé de Bogotá), Conventos, t. 27, f. 789r - v. 
Y especialmente porque durante el tiempo de su gobierno no les habían "pagado los réditos de los juros que poseían en las reales cajas debiendo al convento" 3.652 p. Proponía que de los principales guardados en la Caja de Depósitos, se sacara el dinero para pagar a "Su Magestad" el seis por ciento de las rentas del convento, según estaba mandado. Cuando la Caja Real pagara los juros, la suma sería repuesta. El incumplimiento en el pago de réditos por parte de la Real Caja evidenciaría la permanente crisis fiscal de la Corona. ${ }^{119}$

El dinero recibido de la redención de los principales era guardado en la Caja de Depósitos del Convento bajo tres llaves. La primera alusión a ésta clase de dineros se encontró en la relación jurada del contador Pedroso ${ }^{120}$ cuando entre 1661 y 1664, al restar de los ingresos los gastos, obtuvo un valor de 19.234 p., de los que dice son líquidos 18.944 p. que permanecieron en poder del convento "para la fábrica de las casas y tiendas de la Calle Real". ${ }^{121}$

En 1735, ${ }^{122}$ hay una alusión directa a los principales entregados en la Caja de depósitos. Allí se registran los valores redimidos por diferentes vecinos, entre quienes se encontraba el procurador de la Compañía de Jesús, el rector del noviciado, y el procurador de la misma Compañía. El hecho de que los jesuitas fueran los que más redimieron censos durante éste año indica que la economía de sus haciendas iba en aumento respecto al siglo anterior, ${ }^{123}$ cuando tuvieron que prestar a censo a las clarisas.

\section{LAS FUNCIONES SOCIALES DEL MONASTERIO}

En palabras de Susan Soeiro, ${ }^{124}$ se puede afirmar que "los conventos refle-ian las actividades fundamentales de la sociedad, desde las más comunes

${ }^{114}$ Para corroborar ésta información sería preciso realizar una investigación acerca de las cuentas de la Caja Real de Santafé de Bogotá. Lo cual excede los propósitos de éste trabajo.

115 A.G.N. (Santafé de Bogotá), Conventos, t. 77, ff. 768r - 864v.

116 A.G.N. (Santafé de Bogotá), Conventos, t. 77, ff. 836r - 837r.

117 A.G.N. (Santafé de Bogotá), Conventos, t. 46, ff. 285r - 299v.

118 Germán Colmenares, Haciendas de los jesuitas en el Nuevo Reino de Granada, Bogotá, Antares Tercer Mundo, 1969, p. 24 "[...] la actividad económica de los jesuitas fue un hecho excepcional. Dentro de las limitaciones de magnitud de la economía colonial esta actividad sobrepasaba todo límite conocido para una entidad individual [...] la coordinación de actividades, la centralización contable y, sobre todo, la amplitud de los mercados alcanzados por la actividad de la Compañía permiten analizarla como si se tratara de una empresa económica."

119 Susan Soeiro, "Las órdenes femeninas en Bahía, Brasil, durante la Colonia: implicaciones económicas, sociales y demográficas. 1677-1800", Asunción Lavrin, Las mujeres latinoamericanas. 
hasta las más extravagantes, a pesar de ser instituciones distintas a las del mundo ordinario". Los documentos ${ }^{125}$ remiten a un amplio espectro de estratos de mujeres enclaustradas, desde las esclavas de las religiosas, hasta las monjas de velo negro, descendientes de encomenderos, hijas de presidentes, gobernadores, regidores, capitanes. También convivían las criadas, las niñas familiares de las religiosas, las monjas de velo blanco y las mujeres viudas.

Las fundadoras encabezadas por Damiana de San Francisco, hermana de los Arias Ugarte, quien fuera priora del convento del Carmen, y Juana de Jesús e Isabel de la Trinidad, sus sobrinas religiosas profesas del mismo convento ${ }^{126}$ carmelita, ejemplifican los privilegios otorgados por los lazos de parentesco. Después de ellas las primeras beneficiadas ${ }^{127}$ fueron las hijas del oidor y presidente Lesmes de Espinoza Saravia. ${ }^{128}$

Desde 1629, el primer año en que se llevaron a cabo las profesiones de religiosas se marcaron las diferencias. A través de las monjas de velo negro se formaban las redes por donde circulaba el crédito. De este grupo se escogían las abadesas, vicarias, definidoras, secretarias, maestras de novicias; es decir, todas las que tenían poder para decidir. Kathryn Burns ${ }^{129}$ afirma en su estudio sobre los conventos cuzqueños del siglo XVII, que sólo las monjas de velo negro podían votar en las elecciones conventuales y ocupar cargos de mando. La red de favores tejida entre el convento santafereño y los funcionarios pudo ser reconstruida a través de los lugares que al morir dejaban las religiosas beneficiadas por el patrón: Isabel de Ortega y Prada (1691), hija huérfana del contador Gerónimo de Ortega, Magdalena Dávila (1694), hija del capitán Alonso Dávila Maldonado y Juana de Mesa, y nieta de Gerónima Maldonado, viuda clarisa; Juana María de San Esteban ${ }^{130}$

125 A.C.S.C. (Santafé de Bogotá) y A.G.N. (Santafé de Bogotá).

126 A.C.S.C. (Santafé de Bogotá), Copia manuscrita del protocolo original de la Escritura de Fundación, f. 6 r.

127 A.G.N.(Santafe de Bogotá), Conventos, t. 67, Libro de las licencias para entrar religiosas en el Convento de Santa Clara en Santafé. Año 1640 enero 1, fs. 621r-v.

${ }^{12 S}$ Germán. Colmenares. Historia económica, $j>$. 431. De quien el autor afirma que casó una de sus hijas, posiblemente la mayor, con Pedro de Osma Sanabria, lo que le valió a éste último el otorgamiento de una encomienda.

129 Kathryn Burns. "Conventos" p. 314.

20 Pilar de Zuleta, "En la Santafé del siglo XVII - Doña Francisca Zorrila 'una perfecta casada"', Revista Credencial Historia, Santafé de Bogotá, mayo de 1996. 
(1657), hija del doctor Gabriel Álvarez de Velasco y Francisca Zorrilla. ${ }^{131} \mathrm{O}$ las Pastrana; Inés, Antonia, y Sebastiana (1663), e Isabel (1669), Sebastiana, hija natural, (1663), hijas del contador mayor de la Real Audiencia don Sebastián Pastrana y de doña Ana María Pretel. María de San Lorenzo (1663), hija del contador Domingo Marroquín. Isabel María de Ricaurte y León (1687), hija del tesorero de la Real Casa de Moneda, el capitán Joseph de Ricaurte. La otra Pastrana, Bárbara de la Trinidad (1689), hija del mismo contador Sebastián de Pastrana y de su segunda esposa, doña Margarita de Pisa. Tomasa de Mesa (1692), hija del caballero de la orden de Santiago y capitán Joseph Cortés de Mesa, y Gertrudis de Capiayn, muy posiblemente hermana del marido de la patrona del convento. O Manuela Delgado (1692), hija del maestre de campo y familiar del Santo Oficio Joseph Delgado. Dentro de las postulantes es notoria la fuerte relación con las familias más acaudaladas del Nuevo Reino como el caso de Gerónima Dávila Maldonado (1659) y María Dávila Maldonado (1660) hijas del contador Alonso Dávila Gaviria y de doña Gerónima Maldonado de Mendoza.

Muchas veces las hijas no casaderas de la misma familia ingresaban a la clausura, como el caso de las Pastrana, o de las Maldonado, con lo cual se trasladaban al interior del convento fragmentos enteros de estructuras familiares, las cuales, como en los conventos europeos anteriores a la reforma tridentina, seguramente ejercían bastante poder tanto al interior como al exterior de la clausura.

Un ejemplo claro de las influencias familiares ejercidas a través de las religiosas de velo negro es el caso de la viuda y religiosa clarisa Gerónima Maldonado. Observando el árbol genealógico de la familia Maldonado elaborado por Juan Flórez de Ocáriz ${ }^{132}$ encontramos que ésta familia descendiente de Alvarez Maldonado, señor de la Casa de Cal de Caldereros, de la ciudad de Salamanca, tuvo varias monjas clarisas, numerosos censos otorgados a diversos miembros de la familia, y el préstamo de dinero a censo

${ }^{131}$ Germán Colmenares, Historia económica, p. 439- Francisca Zorrilla era hija de Catalina de Ospina, y Diego Zorrilla, oidor en Quito. A su vez Catalina era hija de Francisco Ospina Maldonado y Ana Maldonado de Mendoza. Francisco, era hijo de Diego Ospina, minero y encomendero de Remedios y gobernador de Neiva.

132 Juan Flórez de Ocáriz, Libro primero de las Genealogías del Nuevo Reino de Granada, Madrid, Real Capilla de Su Magestad, 1674, 2 Tomos, Anexo: Árbol de los Maldonado. 
Las cuentas de 1736 a $1760,{ }^{138}$ que registran egresos para el mantenimiento de "las escuelas de las señoras Pastranas" y el comentario del genealogista Flórez de Ocáriz sobre la madre clarisa Gregoria de Jesús "[...] muy caritiva y dada a criar niñas, cultivando estos nuevos árboles para Dios y industriandolas como buena Maestra [...]", ${ }^{139}$ indican de la existencia de una escuela para niñas dentro del convento de Santa Clara. Aunque sólo fuera hasta 1796, cuando por cédula real ${ }^{140}$ la corona legisló sobre la admisión de niñas en los monasterios de religiosas de los reinos de Indias, para su educación.

Lo que estaba severamente prohibido por Roma era que el convento se convirtiera en lugar de paso o de refugio temporal de mujeres que, como las divorciadas, deseaban refugiarse allí temporalmente debido a su difícil situación dentro de la sociedad. Joan de Capiayn marido de María Arias de Ugarte, patrona del convento de Santa Clara a petición de ella solicitaba al arzobispo, refiriéndose a un breve expedido por el Papa, el derecho a que

"[...] de ninguna manera se admitan mujeres seculares en el dho. convento aunque sea por causa de divorcio o nulidad que las sobredichas pretendan $[, . .]^{141}$

Las religiosas aceptaron el mandato de no ingresar mujeres seculares bajo ningún pretexto que no fuere el de entrar en religión. Sin embargo tras el acatamiento monacal de la bula papal, al reverso del mismo folio firmado por 39 religiosas en noviembre de 1650 el arzobispo fray Cristóbal de Torres ordenó su ejecución, con la salvedad de reservarse él la posibilidad de permitir entrar en el convento a ciertas personas con autorizaciones papales. Este hecho muestra cómo en las alejadas tierras de ultramar, no solamente se ejercían las leyes monárquicas de manera acomodada, sino también las leyes eclesiásticas, según la conveniencia de los poderes locales. Tan cierto

\footnotetext{
${ }^{138}$ A.G.N. (Santafé de Bogotá), Conventos, t. 76, ff. Ir - 23v; Conventos, t. 67, ff. 279r- 294v; Conventos, t. 58, 939r - 954v; Conventos, t. 76, ff. 38r - 57v; Conventos, t. 67, ff. 259r - 273v; Conventos, t. 67, ff. 569r -584v; Conventos, t. 67, ff. 585 - 600r.

139 Juan Flórez de Ocáriz, Libro primero de las Genealogías, vol. 1, p. 233.

140 A.G.N. (Santafé de Bogotá), Conventos, t. 77, ff. 457r - 459r.

141 A.C.S.C. (Santafé de Bogotá), Carta manuscrita de Joan de Capiayn. Proveída por el Arzobispo Francisco Cristóbal de Torres, el 9 de septiembre de 1650, y respuesta escrita por la abadesa Juana de Jesús y firmada por las religiosas, ff. Ir - 2v.
} 
es esto que un siglo después, en diciembre de $1750,{ }^{142}$ el cardenal Catralchin congregado en Roma, comunicaba a su sala capitular que la abadesa Josepha de San Ignacio suplicaba por la tranquilidad espiritual de las monjas:

"[...] humildíssíma suplicante por las señoras Vírgenes, [...] espone, que en el mismo monasterio alguna ves se colocan mugeres, por modo de deposito. Por lo que se originan graves daños, como lo enseña la experiencia, y no pocos detrimentos á la quietud de aquella religiosa comunidad, [...] para evitarlos en adelante suplica humildemte a los eminentísimos señores, se dignen de escrebir al Illmo. Sr. Arzobispo de Sta. Feé para q. por su pastoral Zelo, y Vigilancia probea á la tranquilidad espiritual de las monjas; no permitiendo q. en lo venidero, por ningun pretexto, se recivan por modo de deposito mugeres de qualquier grado, [...] contra la voluntad de las monjas f...]"143

El convento colonial femenino, así no lo aceptaran las religiosas de velo negro, fue concebido por las instancias eclesiásticas como un lugar de refugio para mujeres socialmente incómodas a las cuales había que cuidar para evitar que cayeran en la prostitución o la mendicidad.

El grueso de los pleitos del convento tuvo que ver con el incumplimiento en el pago de los réditos y principales de censos sobre propiedades urbanas y rurales. Tras los incumplimientos de los pagos venían los largos litigios con la formulación primero de acreencias, luego las demandas y finalmente los remates de los bienes. Algunos procesos duraron hasta 81 y más años ${ }^{144}$ pasando de un siglo a otro, de una generación a otra por herencia, o de un deudor a otro por compraventa. Uno de los casos más dramáticos e ilustrativos de la crisis de la encomienda como unidad productiva, y de los encomenderos como grupo social económica y políticamente activo durante el siglo XVI, está representado en la deuda adquirida en 1636, por el regidor y encomendero Joseph de Rojas y su madre Catalina Bolívar. ${ }^{145} \mathrm{El}$ censo fue asumido por 1.520 p. para redimir otro que tenía sobre sus casas

${ }^{12}$ A.C.S.C. (Santafé de Bogotá), Carta manuscrita de la abadesa Josepha de San Ignacio.

${ }^{143}$ A.C.S.C. (Santafé de Bogotá), Carta manuscrita de Joan de Capiayn. Proveída por el Arzobispo Francisco Cristóbal de Torres, el 9 de septiembre de 1650, y respuesta escrita por la abadesa Juana de Jesús y firmada por las religiosas, f. 2r.

${ }^{144}$ A.G.N. (Santafé de Bogotá), Convenios, t. 77, ff. 227r - 272v.

145 A.G.N. (Santafé de Bogotá), Conventos, t. 77, ff. 227r - 272v. 
y haciendas, en favor de dos capellanías. Argumentaba que era "mayor comodidad" deberle al convento. Para ello censó su casa en la plazuela de San Francisco, tres estancias de pancoger que tenía en su encomienda de Cucunubá, dos estancias de ganado mayor en una vereda colindante con la laguna de Suesca, y cinco estancias de ganado mayor pobladas con 300 cabezas de ganado vacuno. Pagarían la deuda a dos años. A los veinte, el convento mandó pregonar el remate de sus bienes por falta de pago de los réditos de seis años. Se pregonaron muchas veces sin que apareciera ningún postor, entonces quién había sido su amigo el oidor González solicitó en 1657, que se sacaran los muebles valiosos de su casa para venderlos y pagar los costos de las diligencias, y le notificó al corregidor del partido de Cucunubá el embargo de las "demoras". En 1659, el sindico del convento nuevamente le cobraba, entonces el encomendero pedía que no le embargaran las "demoras" para con ellas poder pagar lo adeudado al convento. El regidor solicitaba que no le imposibilitaran todos los caminos, estaba acorralado. Las "demoras" no habían podido ser embargadas por cuenta de la Caja Real por deuda del regidor con Su Magestad. Pidió cuatro días para resolver el asunto, pero se convirtieron en ocho años. El 7 de julio de 1664, otro antiguo amigo suyo el alguacil mayor Pedro Gómez le notificó "estando el regidor en la cama" el mandamiento de ejecución de sus bienes. En 1886,22 años después, su viuda, María de Rojas pagaba con carneros parte de la deuda de los réditos.

\section{CONSIDERACIONES FINALES}

Lo económico y lo material, estaban indisolublemente unidos al mundo de la salvación del alma, por las creencias de la sociedad y por la administración que de ellas y del dinero, hacían la Iglesia y la Corona. Entonces no existía esa división contemporánea entre bienes materiales y bienes espirituales. Era precisamente la acertada administración que de los bienes materiales hacía el convento de Santa Clara de Santafé, a través de las diferentes figuras de la economía espiritual lo que aseguraba la salvación del alma.

El sistema contable de las clarisas observado a través de sus libros de cuentas, así como su actividad económica basada en las redes de crédito y la movilidad de bienes inmuebles rurales y urbanos que circulaban a través de éstas redes, demuestran la habilidad financiera de ésta institución religiosa neogranadina. 
Este vínculo entre la religión cristiana y los orígenes de sistemas de crédito tan presentes dentro del capitalismo de los siglos XIX y XX, remite a cuestionar el planteamiento de la influencia del espíritu protestante en la conformación del capitalismo, tal y como lo planteó Max Weber. ${ }^{146}$ Kurt Samuelsson, ${ }^{147}$ afirma, que la doctrina sobre la diligencia de los siglos XVI, XVII y XVIII, no fue exclusiva del protestantismo y el calvinismo. Constituía una característica importante de la moral del mercantilismo que reinaba en todas partes. Lutero conservó el enfoque católico del interés, mientras que Cal vino descartó el pecado de la exacción de interés. Después de la Reforma, el catolicismo conservó en principio su actitud negativa frente al interés, pero relajó poco a poco su condena, hasta convertirse en una norma ética que permitía todas las desviaciones necesarias para la vida práctica.

Según Samuelsson, la prohibición dogmática fue levantada primero que todo respecto a los préstamos de los propietarios agrícolas, pero recibió su golpe mortal a finales del siglo XV por los franciscanos, quienes en $1463,{ }^{148}$ en Orvieto establecieron fundaciones benéficas de préstamos a los pobres. Con el objetivo de cubrir los gastos de administración cargaban un interés sobre los préstamos. La oposición suscitada entre los dominicos fue respondida con un argumento práctico: aunque los préstamos sin interés para los pobres serían los mejores, el bajo interés impuesto a los préstamos de fondos caritativos era mejor que el interés elevado que cobraban los prestamistas profesionales. En 1515 el Concilio Laeterano aceptó este argumento. Así, el "nuevo" concepto del interés surgió en la práctica antes de la Reforma protestante. Afirma dicho autor que la concepción calvinista no explica, como lo suponía Weber, esta fase del capitalismo. El enfoque de Calvino no se diferenciaba del de la mayoría de católicos. Después de mucha meditación y deliberación se declaró que la imposición a interés no estaba prohibida en todos los casos. De todas maneras se imponían bastantes condiciones. Se aconsejaba prudencia: era mejor obtener menos ganancias que sobrepasarse demasiado.

Como lo anota Samuelsson ${ }^{149}$ la praxis económica pudo haber seguido su propio camino y sus propias "leyes" sin preocuparse por el concepto canó-

\footnotetext{
${ }^{146}$ Max Weber, La ética protestante y el espíritu del capitalismo, México, Premia - La red de Jonás, 1979. Kurt Samuelsson, Religión y economía, Madrid, Marova y Barcelona, Fontanella, 1970

${ }^{147}$ Ibid,p. 151.

${ }^{148}$ Ibid, p. 153.
} 
nico o calvinista de la justicia. Las modificaciones de las concepciones religiosas (ya se sostenga que tuvieron lugar dentro del catolicismo, o, dentro del protestantismo) no significan en este caso la creación de una nueva libertad. El nacimiento del capitalismo, está más ligado a las tasas bajas de interés que a las altas. El ejemplo más notable de progreso económico es el de los Países Bajos que a comienzos del siglo XVIII tenían tasas de interés que oscilaban entre el dos por ciento (2\%) y ocasionalmente el uno tres cuartos por ciento $\left(\mathrm{l}^{3} /{ }_{4} \%\right) .{ }^{150}$ Las tasas bajas ofrecieron un efecto estimulante en las empresas, el comercio y la industria al hacer más atractivas las inversiones reales que las transacciones puramente financieras. Las minas profundas, las fábricas sólidamente establecidas, los canales bien abiertos y las casas firmes de la revolución industrial fueron construidas con un capital relativamente barato. La opinión tradicional católica coincidía con los autores protestantes en considerar al interés, sobretodo cuando era demasiado elevado, como un mal moral.

La iglesia católica en América Latina, tal y como la entiende Bauer, ${ }^{151}$ tuvo éxito durante tres siglos al edificar una vasta organización económica diseñada para generar excedentes que destinó a fines sociales y espirituales. ${ }^{152}$ Durante su actividad no fue una institución monolítica que tomó decisiones económicas centralizadas. La Inquisición, las hermandades laicas, los clérigos y las religiosas se involucraron en diversos negocios a través del préstamo de dinero a interés. Se podría, según este mismo autor, imaginar a la iglesia católica como una superestructura de aprobación de ingresos sumamente vasta, construida con el tiempo en variados estilos que se apoyaron en una amplia gama de actividades económicas. El soporte más importante de ésta construcción serían las gruesas columnas de los ingresos del diezmo,

"[...]flanqueadas por pilares iguales o aún más grandes de los ingresos procedentes de miles de capellanías, fondos píos, tierras, rentas y arrendamientos a largo plazo de propiedades y, finalmente, los residuos de los contrafuertes, mucho más reducidos, procedentes de los ingresos de préstamos con intereses, cuotas clericales, subvenciones municipales e inversiones y comercio diverso a título individual". ${ }^{153}$

151 A. J. Bauer, La iglesia en la economía, p. 13.

152 ¡bid,p.47.

153 Ibid. pp. $14-15$. 
El imperio económico de propiedades y maquinaria fiscal de la iglesia comenzó a ser cuestionado en el siglo XVIII, cuando el estado borbónico puso sucesivas demandas de contribuciones económicas a la iglesia americana. En 1767 los jesuitas fueron expulsados de todo el imperio español. El ataque sobre el clero regular iniciado por los borbones fue continuado por los gobiernos republicanos. Ya para la década de 1860, las órdenes femeninas y masculinas en toda América habían sido, o bien destruidas por la fuerza, o simplemente abolidas ${ }^{154}$ y expropiadas. Con la exclaustración y la desamortización de bienes de manos muertas impuestas por el general Mosquera en Colombia, en 1861, las clarisas bogotanas volvieron a vivir de acuerdo con su voto de pobreza franciscana. Entonces las instituciones bancarias formales comenzaron a surgir por todas partes.

${ }^{154}$ Ibid. p.48. 